NBER WORKING PAPER SERIES

MARRIAGE MEETS THE JONESES:

RELATIVE INCOME, IDENTITY, AND MARITAL STATUS

Tara Watson

Sara McLanahan

Working Paper 14773

http://www.nber.org/papers/w14773

\author{
NATIONAL BUREAU OF ECONOMIC RESEARCH \\ 1050 Massachusetts Avenue \\ Cambridge, MA 02138 \\ March 2009
}

The authors thank Martha Bailey, Betsy Brainerd, Erika Franklin Fowler, Dave Frisvold, Claudia Goldin, Leslie Hinkson, Erzo Luttmer, Edward Norton, Lucie Schmidt, Lara Shore-Sheppard, participants in the MacArthur Network on Inequality, participants in the Fragile Families workshop, participants in the Population Association of America meetings, participants in the Williams College Economics Brown Bag, and participants in the University of Michigan Labor Lunch for valuable comments. The views expressed herein are those of the author(s) and do not necessarily reflect the views of the National Bureau of Economic Research.

NBER working papers are circulated for discussion and comment purposes. They have not been peerreviewed or been subject to the review by the NBER Board of Directors that accompanies official NBER publications.

(C) 2009 by Tara Watson and Sara McLanahan. All rights reserved. Short sections of text, not to exceed two paragraphs, may be quoted without explicit permission provided that full credit, including $\odot$ notice, is given to the source. 
Marriage Meets the Joneses: Relative Income, Identity, and Marital Status

Tara Watson and Sara McLanahan

NBER Working Paper No. 14773

March 2009

JEL No. J12

\begin{abstract}
$\underline{\text { ABSTRACT }}$
In this paper we investigate the effect of relative income on marital status. We develop an identity model based on Akerlof and Kranton (2000) and apply it to the marriage decision. The empirical evidence is consistent with the idea that people are more likely to marry when their incomes approach a financial level associated with idealized norms of marriage. We hypothesize that the "marriage ideal" is determined by the median income in an individual's local reference group. After controlling flexibly for the absolute level of income and a number of other factors, the ratio between a man's income and the marriage ideal is a strong predictor of marital status - but only if he is below the ideal. For white men, relative income considerations jointly drive co-residence, marriage, and fatherhood decisions. For black men, relative income affects the marriage decision only, and relative income is tied to marital status even for those living with a partner and children. Relative income concerns explain 10-15 percent of the decline in marriage since 1970 for low income white men, and account for more than half of the persistent marriage gap between high- and low-income men.
\end{abstract}

Tara Watson

Williams College

Department of Economics

Williamstown, MA 01267

and NBER

tara.watson@williams.edu

Sara McLanahan

Princeton University

265 Wallace Hall

Princeton, NJ 08544

mclanaha@Princeton.EDU 


\section{Marriage Meets the Joneses: Relative Income, Identity, and Marital Status}

It is well known that low-income men are less likely to marry. Among 25-34-year-old white men in the 2000 Census, for example, 34 percent of those in the bottom quarter of the income distribution are married, compared with 67 percent of those in the top quarter of the income distribution. For blacks, the numbers are 16 percent and 50 percent respectively. ${ }^{1}$ A number of social and economic explanations for this phenomenon have been proposed, many focusing on the role of economic security in determining whether a man is "marriageable." Here, we explore the possibility that relative income is an important determinant of the marriage decision. We build on Easterlin's (1980) suggestion that income relative to aspirations affects marriage and childbearing.

Our theoretical framework borrows heavily from Akerlof and Kranton's (2000) model of identity. We hypothesize that people marry in part to gain utility from thinking of themselves in the category of "married people." This category entails certain prescriptions for behavior and characteristics, including a particular standard of living associated with marriage. When couples are far from achieving this norm, they benefit less from marrying, and therefore are less likely to do so. We hypothesize that the income associated with an ideal marriage is not absolute, but differs depending on a couple's reference group. Empirically, we explore reference groups determined by metropolitan area, race, and education.

This paper contributes to a growing literature which attempts to isolate the causal influence of relative income on a diverse set of behaviors and outcomes. Recent and historic work has explored the link between relative income and subjective well-being (Clark et al (2008), Luttmer (2005), and others), health outcomes and health behaviors (Miller and Paxson (2006), Eibner and Evans (2005), and others), female labor supply

\footnotetext{
${ }^{1}$ These figures exclude men living in group quarters. Married refers to currently married and living with a spouse. White men are native-born non-Hispanic white men; black men are native-born non-Hispanic black men. The analysis to follow is restricted to those residing in sample metropolitan areas; marriage rates for the sample exhibit similar disparities between high- and low-income men.
} 
(Neumark and Postlewaite, 1998)), consumption and savings (Denizer et al, 2000, Kosicki, 1987, Duesenberry, 1949), homeownership (Withers, 1998), suicide (Daly, Wilson, and Johnson, 2007), social capital (Fischer and Torgler, 2006), and even soccer performance (Torgler and Schmidt, 2007).

The paper proceeds as follows. Section I discusses the link between income and marriage. In Section II, we develop a simple theoretical framework which incorporates the notion of identity to the marriage decision. We then offer a descriptive analysis of marriage patterns across metropolitan areas in Section III. Section IV describes the data and empirical strategy, and section V reports results. Section VI presents the results of simulations that assess the importance of relative income in explaining declining rates of marriage over time and the marriage gap between high- and low-income men. Section VII concludes.

\section{Income and Marriage}

Figures 1a, 1b and 1c illustrate two stylized facts. First, there is a strong positive relationship between a man's income and marital status in the U.S. in each Census year between 1950 and 2000. The correlation is strongest at the bottom of the income distribution but weakens for men at the top of the distribution. Second, at each level of income, marriage rates have fallen in every decade since $1960 .^{2}$ Declines in the probability of being married are particularly evident between 1970 and 1990 for all three groups of young men studied - native non-Hispanic white, native non-Hispanic black, and native Hispanic men.

Our main analysis focuses on the years 1980-2000. During that period, there was a roughly 15 percentage point decline in marriage for young white men across the income distribution (see Table 1). Declines for black men were 11 to 18 percentage points and greatest in the second quartile of the income distribution. Table 1 indicates that these

\footnotetext{
${ }^{2}$ The probability of being married at any given income level is similar in 1950 and 1960 . However, as is evident from Table 1, there was a rise in the overall likelihood of being married between 1950 and 1960 associated with rising incomes.
} 
changes represent a larger percentage change in marriage at the bottom of the income distribution for all groups. In the bottom quartile of 25-to-34 year old white men, for example, about 49 percent of men were married in 1980 and only 34 percent were married in $2000 .^{3}$ The decline was from 27 to 16 percent for black men and from 48 to 24 percent for Hispanic men.

Why do declines in marriage matter? Although it is difficult to separate the selection into marriage from its causal influence, marriage is associated with a wide range of beneficial outcomes for the married individuals, their children, and society more broadly. Marriage promotion is also a key underpinning of recent anti-poverty efforts. The 1996 welfare reform (PWRORA) controversially emphasized marriage as a means to ending welfare dependency, and policy efforts to strengthen marriage have continued since that time (Lerman, 2002). Understanding why couples, and particularly low-income couples, choose to marry or not marry is therefore of heightened policy interest.

As noted in a recent review article by Burstein (2007), economic models suggest reasons why the poor might be either more or less likely to marry. The classic economic model of marriage posited by Becker (1981) hinges on specialization in home production. The gains from specialization and public goods (Lam, 1988) might be particularly important to a disadvantaged couple. On the other hand, if men's earnings are low relative to women's at the bottom of the distribution, the gains from specialization are muted and marriage becomes less likely among disadvantaged couples. Furthermore, tax policy and means-tested social insurance programs may discourage marriage, and the disincentives might be particularly pronounced at the bottom of the income distribution. ${ }^{4}$

The structure of marriage markets also plays a potentially important role in discouraging marriage at the bottom of the income distribution. Loughran (2002) and Gould and Paserman (2003) document the negative effect of rising male income inequality on

\footnotetext{
${ }^{3}$ Figures exclude men living in group quarters. Numbers are similar in our sample of metropolitan men.

${ }^{4}$ Burstein (2007) includes a review of the empirical literature on the relationship between marriage and tax and transfer policy. While the tax code and transfer policy generate significant marriage penalties and subsidies for some couples, the evidence generally indicates small effects of these incentives on marriage decisions.
} 
marriage rates, arguing that income dispersion extends the female search process. Willis (1999) posits that uneven sex ratios and adequate support for single mothers can lead to an equilibrium in which low-income men remain unmarried and father children with multiple partners.

The economic models of specialization and marriage markets suggest that low-income men may be less likely to form stable co-residential partnerships. However, economic theory is largely silent on how income affects the decision to marry once such partnerships are formed. ${ }^{5}$ Unmarried cohabitation is an increasingly common status; in the 2002 National Survey of Family Growth 50 percent of women aged 15 to 44 had cohabited at some point and 59 percent of marriages were preceded by cohabitation (Stevenson and Wolfers, 2007). A large majority of cohabiters expect or hope to marry (Lichter, 2006). Still, a majority of cohabiting unions do not transition to marriage in five years, either because of dissolution or inertia. More than a fifth of cohabiting couples in 2002 had been living together at least five years (Stevenson and Wolfers, 2007). These facts imply that barriers to marriage exist among co-residing couples.

Qualitative work by Gibson-Davis, Edin, and McLanahan (2005) suggests that financial status affects the marriage decision even among co-residing couples with children. ${ }^{6}$ Although all of the couples in the Gibson-Davis et al. study have young children together and a majority co-reside, many opt to postpone marriage for financial reasons. Respondents repeatedly point to markers of a middle class lifestyle as pre-requisites for marriage, though the perceived necessities vary across individuals. ${ }^{7}$ In many cases, because the stated financial goals are unlikely to be attainable, the high financial expectations associated with marriage are likely to preclude marriage for the foreseeable future. The notion that couples perceive financial security as a pre-requisite to marriage,

\footnotetext{
${ }^{5}$ Because tax and transfer policy are sensitive to marital status per se, such policy might influence whether co-residential partners marry. In the analysis, we control for state AFDC generosity and include year fixed effects to account for national changes in tax policy.

${ }^{6} \mathrm{We}$ describe couples sharing a household as co-residing whether married or unmarried; we refer to unmarried co-residing couples as cohabiting.

${ }^{7}$ Examples include a washer-dryer, a single-family house with a garage, a couples "own place", a car, and a big wedding. We suspect that the financial level viewed as necessary for marriage depends on an individual's reference group.
} 
even after choosing to live and bear children together, suggests that existing economic models offer an incomplete picture of the marriage decision.

Here we invoke the concept of identity developed by Akerlof and Kranton (2000) to explain the puzzle. The decision of a couple to marry once a co-residential partnership has been formed is largely the decision to identify publicly and privately as a married couple. The Gibson-Davis et al. study suggests that marriage is associated with a set of prescriptions (norms) for behavior and financial status. Without the financial wherewithal to meet these expectations, cohabitation is preferable to marriage. One couple in the study, for example, is embarrassed to publicly acknowledge their marriage because they lack financial independence and still live at home. Translated into the Akerlof and Kranton (2000) identity framework, a couple failing to achieve the financial prescriptions associated with marriage suffers a utility loss if they choose to enter the category of married people.

The notion that marriage is associated with the realization of financial norms is not new. Easterlin (1980) posits that couples aspire to a certain standard of living before marrying. Wilson (1987), Oppenheimer, Kalmjin, and Lim (1997), and Brown and Kesselring (2003) argue that male "marriageability" is contingent on steady employment or a minimum level of earnings. Qualitative work by Edin (2000) and Gibson-Davis, Edin, and McLanahan (2005) also points to the importance of financial stability as a precursor to marriage.

Less clear is how such financial prescriptions are determined. Easterlin (1980) suggests that financial aspirations stem from the standard of living one experienced as a young adult. But the Gibson-Davis et al. respondents appear to reference a set of norms extending beyond their own life experiences. Here we analyze local reference groups for example, those comprised of others in one's own metropolitan area, race/ethnicity, and/or education category. We are guided by the theme of a "middle class lifestyle" that runs throughout the Gibson-Davis et al study; we assume that the ideal income targeted by men is that of the median fully employed man in his reference group. However, we 
also explore how the theoretical middle class marriage ideal compares to empirically "estimated ideals" which are generated based on marriage patterns in the data.

Our theoretical framework abstracts from marriage market considerations and the search process. Empirically, we address the marriage market issue in two ways. First, in the main analysis, we control for race/ethnicity-specific sex ratios in the metropolitan area and a man's rank in the local race/ethnicity-specific income distribution. Second, we replicate the main analysis restricting the sample to those men already living with a partner. We expect marriage market search considerations to be considerably dampened for co-residing men.

\section{A Model of Income, Identity, and Marriage}

Suppose a locality has an equal number of men and women in the marriage market. Each person is endowed with income drawn from the same distribution. Suppose further that the desirability of men and women is represented by their income $Y_{i}$. We abstract from the matching process and assume men and women are matched by the level of income such that within each couple the man and the woman have equal levels of income. The couples may decide to cohabit or marry. The value of marrying is determined by background characteristics (such as age, education, race, income, characteristics of peers) which in turn affect the financial returns and personal returns to marriage. For example, married couples might receive financial benefits or incur costs because of tax and welfare policies that interact with their level of income. The personal returns include social rewards for marriage from family and friends as well as the effect of marrying on one's self-image.

Following the model of identity outlined in Akerlof and Kranton (2000), we describe "married people" as one group $c$ in a set of social categories $\mathbf{C}$ with which men and women may choose to identify. Prescriptions $\mathbf{P}$ describe the ideal characteristics and behavior for each category. For example, married people might be expected to have a high level of income, to live in their own residence apart from extended family, to stay 
home instead of going to the bar, and to exhibit high levels of paternal involvement in childrearing.

We assume the category "cohabiting people" has no set of prescriptions. While this is a simplification, the financial hurdle for cohabitation is likely to be much lower than that for marriage. In a study of the relationship between education, marriage and cohabitiation, Thorton, Axinn, and Teachman (1995) posit that schooling and the associated earning power may be less important for cohabitation than for marriage. The qualitative evidence from Gibson-Davis, Edin, and McLanahan (2005) also suggests that cohabitation involves weaker financial prescriptions; many respondents already lived together but viewed their economic situation as inadequate for marriage.

An individual's self-image $I_{i}$ depends on the match between his or her behavior and characteristics with the ideals prescribed for his or her category. In our simple model, we focus on the prescription that married people have a certain level of income. We also allow a random error term $\varepsilon_{i}$ with mean zero to affect an individual's self image associated with any given category. Thus, an individual's utility can be described by:

$$
\begin{gathered}
U_{i}=U_{i}\left(Y_{i}, I_{i}\right) \\
\text { where } I_{i}=I_{i}\left(Y_{i}, c_{i}, \mathbf{P}, \varepsilon_{i c}\right), \\
\partial U_{i} / \partial Y_{i} \succ 0, \text { and } \\
\partial U_{i} / \partial I_{i} \succ 0
\end{gathered}
$$

That is, in general an individual's utility depends on his income and self-image. Selfimage, in turn, is a function of interactions between an individual's income, the category with which he identifies, the prescriptions for that category, and a random error term.

Suppose that the financial prescription for a married person is at least $Y_{\text {ideal }}$, where $Y_{\text {ideal }}$ is the median income of a given reference group. The identity payoff for a married person is then:

$$
I_{i}=I_{\text {mar }}-t\left(\max \left(0,1-\frac{Y_{i}}{Y_{\text {ideal }}}\right)\right)+\varepsilon_{\text {imar }},
$$


where $t$ is a positive scalar describing the identity loss associated with falling below the "marriage ideal". The identity payoff for cohabiting is:

$$
I_{i}=\mathrm{I}_{\text {cohab }}+\varepsilon_{\text {icohab }}
$$

and we assume $\mathrm{I}_{\mathrm{mar}} \succ \mathrm{I}_{\text {cohab }}$. In other words, on average a married person meeting the ideal has a higher self-image than a cohabiting person.

In making the decision whether to marry, an individual compares the utility from cohabiting and marriage. The self-image gained through marriage (relative to cohabitation) is

$$
I_{i}=\left(\mathrm{I}_{\text {mar }}-I_{\text {cohab }}\right)-t\left(\max \left(0,1-\frac{Y_{i}}{Y_{\text {ideal }}}\right)\right)+\left(\varepsilon_{\text {imar }}-\varepsilon_{\text {icohab }}\right)
$$

The gains to self-image through marriage tend to increase with the average gain in selfimage from marriage and an individual's income. The gains decrease with a higher "marriage ideal" and a higher penalty $t$ for deviating from the norm.

This framework provides some simple comparative statics. The gain to marriage is increasing in $Y_{i}$ for $Y_{i}<Y_{\text {ideal }}\left(\frac{\partial I}{\partial Y_{i}}=t / Y_{\text {ideal }}\right)$ and constant in $Y_{i}$ for $Y_{i} \succ Y_{\text {ideal }}\left(\frac{\partial I}{\partial Y_{i}}=0\right)$. Similarly, an increase in the marriage ideal $Y_{\text {ideal }}$ is associated with a decrease in the gain to marriage for low values of $Y_{i}$ but no change in the gain for high values of $Y_{i}$. A higher level of $t$ strengthens the relationship between $Y_{i}$ and marriage below the marriage ideal, and reduces the overall marriage rate holding other factors constant.

The model assumes that $Y_{\text {ideal }}$ is the median income of a relevant reference group. We follow this approach in the empirical work, defining reference groups to consist of fully employed working age men in the same metropolitan area, race/ethnicity group, and/or education group as the individual. In the next section, we examine marriage patterns in the data. We also generate "estimated ideals" from the data and compare them to the theoretical "middle class" ideal of the reference group median. 


\section{Estimated and Theoretical Marriage Ideals}

Figures $1 \mathrm{a}, 1 \mathrm{~b}$, and $1 \mathrm{c}$ demonstrate a positive relationship between marriage and income at the national level for men ages 25 to 34 . The relationship is strongest at the bottom of the income distribution and weaker at the top of the income distribution. These pictures, however, combine men in many metropolitan areas who are likely to have different reference groups and, according to our theoretical framework, different perceptions of the level income required for marriage. If reference groups are formed at the metropolitan area level, the model predicts a significant flattening in the relationship between income and marriage within each metropolitan area.

We visually examine the income-marriage relationship within each metropolitan area, year and race/ethnicity group. Examples of these relationships for white men in selected metropolitan areas are shown in Figure 2. The graphs suggest that, in the white sample, the flattening of the income-marriage relationship is evident within most metropolitan areas and that the apparent point of flattening differs across metropolitan areas. ${ }^{8}$

To describe the income-marriage relationship in each metropolitan area, we consider the following equation:

$$
\operatorname{Pr}\left(\operatorname{mar}_{i}\right)=\alpha_{0}+\alpha_{1} * Y_{i}+\alpha_{2} *\left(Y_{i}^{*} \text { highinc }\right)+\alpha_{3} * \text { highinc }+\varepsilon_{i},
$$

where $Y_{i}$ is an individual $i$ 's income, highinc is an indicator that $Y_{i}$ exceeds some value $j$. In estimating this descriptive model, a significant negative value for $\alpha_{2}$ indicates a flattening of the income-marriage relationship around point $j$. We run this regression multiple times for each metropolitan area and year and race/ethnicity group in our sample using a linear probability model, searching across potential values of $j .{ }^{9}$ Among values of $j$ which yield statistically significant negative values of $\alpha_{2}$, we choose the one generating the regression model with the highest $\mathrm{R}$-squared. The selected value of $j$ represents the

\footnotetext{
${ }^{8}$ The pattern of flattening is less evident in the black sample, as discussed below.

${ }^{9}$ Potential values of $j$ are restricted to those between the $20^{\text {th }}$ and $80^{\text {th }}$ percentile of income of fully employed men in the metropolitan area, year, and race group, and searched over $\$ 500$ increments.
} 
point at which the relationship between income and marriage flattens in the data; we refer to it as the "estimated ideal."."

There is a positive relationship between income and marriage for low-income men within all metropolitan areas. For the white male sample, there is at least one significant negative slope change in the relevant range for 319 of 330 metropolitan area-year cells that is, there is a point of flattening of the income-marriage relationship. The "estimated ideal" is shown as a dashed line for five large metropolitan areas in Figure 2. Figure 2 also includes solid lines representing theoretical "middle class" ideals - the median income of fully employed men in the reference group for each metropolitan area and year.

Means of the estimated ideals for men in the sample are shown in Table 2. The values of the ideals vary substantially across metropolitan areas. For about half of men in the white sample, the estimated ideal falls between the 40th and the 60th percentile of the earnings distribution of fully employed working aged men. ${ }^{11}$ Figure 3 illustrates the correlation between the estimated ideal and the theoretical middle class ideal (median earnings of fully employed men) across metropolitan areas in the white male sample. The estimated marriage ideal is higher in high-income areas.

Table 3 presents regression analysis exploring the link between the estimated ideal and the theoretical middle class ideal. Results indicate that the estimated ideal is closely tied to the theoretical ideal, both across metropolitan areas in any given year and within metropolitan areas over time. A 1 percent increase in median earnings of fully employed men is associated with a 1 to 1.7 percent increase in the estimated ideal, after controlling for metropolitan area fixed effects and other metropolitan area characteristics.

\footnotetext{
${ }^{10}$ This procedure is similar to one used in Card, Mas, and Rothstein (2008) to identify neighborhood tipping points in metropolitan areas.

${ }^{11}$ By construction, the estimated ideal falls between the $20^{\text {th }}$ and $80^{\text {th }}$ percentile of the income of fully employed men in the metropolitan area and race/ethnicity group. For black men, the estimated ideal varies widely; it falls between the $40^{\text {th }}$ and $60^{\text {th }}$ percentiles less than a third of the time.
} 
The pattern of flattening in the income-marriage relationship is less evident in the black sample. Unlike in the white sample, marital status and income are positively related throughout the income distribution for black men in many metropolitan areas. In 57 out of 255 metropolitan area-year cells, there is no statistically significant flattening of the relationship in the relevant range. ${ }^{12}$ Estimated ideals vary widely and are not significantly related to median earnings except in the 1980 cross-section (see Table 3). ${ }^{13}$ The analysis that follows also indicates that models using the race/ethnicity specific reference group do not perform well for the black male sample. Rather, educationspecific reference groups generate results that are consistent with the theoretical framework for black men.

Although there is a point at which the income-marriage relationship flattens in almost all metropolitan areas for white men (and in many metropolitan areas for black and Hispanic men), there are limitations to using the "estimated ideal" in the formal analysis to follow. First, these ideals are chosen to fit the predictions of the model. It is therefore inappropriate to use them to test the validity of the model. Second, the "estimated ideals" are sensitive to outliers in the data.

Instead, we rely on a different proxy for the marriage ideal. The level of income perceived to be required for marriage is unobservable and presumably differs across individuals. In the analysis that follows, we use the median income in a local reference group (which we refer to as the theoretical middle class ideal) as a proxy for the marriage ideal. The qualitative evidence described by Gibson-Davis et al. suggests that lowincome men aspire to a middle class lifestyle prior to marriage, which we define as the median earnings of a fully employed (full-time full-year) man in the relevant reference group. We consider the median income of (1) full employed (full-time full-year) male workers in one's metropolitan area and race/ethnicity group, and (2) fully employed male

\footnotetext{
${ }^{12}$ The relevant range is the $20^{\text {th }}$ through $80^{\text {th }}$ income percentile of fully employed black men in the metropolitan area and year.

${ }^{13}$ For the Hispanic sample, there is no significant flattening in 37 of 121 metropolitan area-year cells, particularly in those cells with small sample sizes. Estimated ideals are noisy for the Hispanic sample.
} 
workers in one's metropolitan area and education group, and (3) fully employed male workers in one's metropolitan area, education group and race/ethnicity group.

The mean values of the theoretical middle class ideals are reported in Table 2. Because the ideal is determined by fully employed adult men of all ages, the income associated with the marriage ideal is higher than that of the median man in the sample; 66-93 percent of men fall below the ideal depending on the sample, year, and reference group. The values of the ideals stay fairly constant over time for the white and black samples and fall for the Hispanic samples. ${ }^{14}$ Due to rising inequality, the ratio of income to the ideal is declining for those below the ideal but increasing for those above the ideal. Couples below the ideal are farther from it, and couples above the ideal increasingly exceed it. For both the white and Hispanic samples, this pattern is evident using all three reference groups with both the one-earner and two-earner methodologies. For the black sample, relative incomes for those below the ideal fell in the 1980s but recovered in the 1990s.

We focus on how male income compares to a male earnings in the reference group. Although couples presumably consider their joint potential income when making the marriage decision, female income is unobservable for many men in our sample. Furthermore, female labor supply is endogenous to the marriage decision. Nevertheless, we also experiment with allowing the "marriage ideal" to be a function of estimated potential earnings of two earners. The two-earner analysis is discussed in the appendix. Results are fairly similar using the one-earner and two-earner approaches.

\section{Data and Empirical Strategy}

We use the 5\% IPUMS sample of the 1980-2000 U.S. Censuses to investigate the determinants of marriage. We limit our analysis to residents of 110 metropolitan areas for which we have housing price data; the metropolitan areas are matched to be as

\footnotetext{
${ }^{14}$ As discussed in the appendix, the two-earner estimated ideals generally increase over time, consistent with increased earnings power for women over the time period.
} 
geographically consistent as possible across three sample years. ${ }^{15}$ We use samples for three demographic groups: native born non-Hispanic white men ages 25-34, native born non-Hispanic black men, and native born Hispanic men ages 25-34. ${ }^{16}$ We choose ages 25-34 so that respondents are likely to have completed school and are observed at a point likely to be close to the timing of their marriage decision. We exclude the foreign born population because some of these individuals may derive norms and expectations about marriage from their home countries.

A limitation of the Census sample is that it is a repeated cross-section rather than a panel. Therefore, we cannot evaluate how the exact timing of the marriage decision relates to the income trajectory for an individual. However, we believe that this disadvantage is outweighed by the very large sample sizes; there are over one million 25-34-year-old men in the non-Hispanic white sample. The large samples allow us to precisely estimate the effects of relative income on marital status while controlling very flexibly for absolute income and a number of other potential confounders.

We use reported total real income last year for each man in the Census sample as a proxy for his earnings at the time of the marriage decision. Income is top-coded and bottomcoded in the public use data. To minimize the effect of top- and bottom-coding, and to exclude non-positive reported incomes, we drop men in the top and bottom 5 percent of each metropolitan area's income distribution in each year. In the samples of black and Hispanic men, we exclude the top and bottom 10 percent.

As noted above, our main analysis assumes that the male in the relationship aspires to the median income of a fully employed (full-time full-year) man within a particular reference group. Models incorporating the potential earnings of women are discussed in the appendix. Throughout the analysis, reference groups are assumed to operate within metropolitan areas. Norms that are perpetuated at a national level (for example, through

\footnotetext{
${ }^{15}$ Thanks to Lara Shore-Sheppard for sharing the metropolitan area match.

${ }^{16}$ To be included in the sample, a metropolitan area must have at least 10018 -to-64 year-old men in the race/ethnicity group in the PUMS for all three Census years. This ensures that the values of the marriage ideal are reliably estimated. The restriction results in 85 metropolitan areas for the native non-Hispanic black sample and 47 metropolitan areas for the native Hispanic sample.
} 
television) are not identified here. Within metropolitan areas, we explore reference groups determined by race and/or education.

According to the theoretical model, the ratio of one's own income to the marriage ideal should affect the marriage decision, but only for those below the ideal. The preferred specification is as follows:

$$
\begin{gathered}
\operatorname{Pr}\left(\text { mar }_{i}\right)=\beta_{1} * \text { under }_{i} * \frac{Y_{i}}{Y_{\text {ideal }}}+\beta_{2} *\left(1-\text { under }_{i}\right) * \frac{Y_{i}}{Y_{\text {ideal }}}+\beta_{3} * \text { under }_{i} \\
\beta_{4} * X_{i}+\gamma_{\text {ycat }}+\alpha_{\text {yrank }}+\sigma_{\text {age }}+\partial_{\text {educyr }}+\theta_{\text {metro }}+\varepsilon_{i}
\end{gathered}
$$

where $\operatorname{Pr}\left(\mathrm{mar}_{i}\right)$ is the probability individual $i$ is married, Under is an indicator suggesting $i$ is below the marriage ideal, $\frac{Y_{i}}{Y_{\text {ideal }}}$ is the ratio of $i$ 's income to the ideal, $X_{i}$ is a vector of individual characteristics, $\gamma_{\text {ycat }}$ is a vector of dummies indicating income categories adjusted for cost-of-living (corresponding to the year-specific percentile rank in the national housing-price adjusted income distribution), $\alpha_{\text {yrank }}$ is a vector of dummies indicating the individual's decile income rank in his metropolitan area (withinrace/ethnicity group), $\sigma_{\text {age }}$ represents individual age dummies, $\partial_{\text {educyr }}$ represents education group-year dummies, $\theta_{\text {metro }}$ indicates metropolitan area fixed effects and $\varepsilon_{\mathrm{i}}$ is an error term. ${ }^{17}$ The key coefficients are $\beta_{1}$, the effect of the ratio for those under the ideal, and $\beta_{2}$, the effect of the ratio for those above the ideal. The theoretical framework predicts that $\beta_{1}$ is positive and $\beta_{2}$ is zero.

In the preferred specification, we control for income quite flexibly. A dummy for each percentile group of the national cost-of-living adjusted income distribution in each year is included in the model, for a total of 300 categories. ${ }^{18}$ Our models include a number of other individual level control variables. Four education categories are included - less

\footnotetext{
${ }^{17}$ The equations are estimated using the linear probability model for ease of interpretation. The main results are qualitatively similar if one uses probit models instead.

${ }^{18}$ The cost-of-living adjustment is calculated using the formula suggested by Albouy (2008), which weights housing-related prices using a 0.36 share of expenditures. Alternative adjustments are used in the sensitivity analysis.
} 
than high school, high school exactly, some college, and college graduate or more - and interacted with year dummies so that the effect of education is allowed to vary over time. Individual age dummies and indicators for the man's employment status and whether he is employed full-time full-year are also included. The preferred specifications incorporate dummies for the individual's decile rank in the metropolitan area.

We incorporate a rich set of metropolitan area control variables as well. All models include metropolitan area fixed effects to account for unobserved characteristics of cities that do not change over time. We also control for demographic and socioeconomic characteristics of the metropolitan residents - fraction native black, fraction native Hispanic, fraction foreign-born, fraction with a high school degree, fraction with some college, fraction with a college degree or more, fraction under 18, and fraction under 65 . We control for the male employment-to-population ratio and predicted male and female employment levels based on 1980 industrial mix. We include additional controls for the race/ethnicity specific sex ratios in the metropolitan area, the ACCRA housing price index, the log of real housing-price-adjusted AFDC/TANF benefits for a family of three in the state, and the $\log$ of the metropolitan area population. ${ }^{19}$

Because we control very flexibly for individual income and metropolitan area fixed effects, the key source of variation stems from a man's relative income - how his income relates to the marriage ideal determined by his reference group. We hypothesize that a low-income man is less likely to marry if he lives in a metropolitan area with highincome men, holding his own income and income rank constant. A sufficiently highincome man, on the other hand, is unaffected by others being rich in his reference group.

Table 4 shows means for each of the three samples. After excluding the top and bottom 5 percent of the national income distribution, those living in group quarters, and those in excluded metropolitan areas, the final sample of native non-Hispanic white men is 1.16 million observations. For black men, the final sample size is roughly 143,000 and for

\footnotetext{
${ }^{19}$ The welfare benefits data are from the University of Kentucky Center for Poverty Research state-level transfer program information, available at www.ukcpr.org.
} 
Hispanic men the sample is about $67,000 .^{20}$ The marriage rate fell by about 15 percentage points between 1980 and 2000 for both the white sample and the black sample; the Hispanic sample experienced larger declines in marriage. Rates of marriage are lowest and rates of cohabitation are highest for the black sample. For all three samples, the average income of sample men remained stable or declined. ${ }^{21}$

\section{Results}

\section{A. Analysis of Native Born Non-Hispanic White Men}

The model suggests that relative income matters to the marriage decision. In particular, a man is more likely to marry when his income approaches a marriage ideal. The ratio of income to the ideal is expected to predict marital status below the ideal, but not above the ideal.

Our results are foreshadowed by Figure 4. Here we divide the white sample into categories based on the ratio of each man's income to the theoretical marriage ideal. In each Census year, the probability of marriage is sharply increasing with the ratio to the ideal until a ratio of 1.0 to 1.3 . Above 1.3, the relationship between the ratio and marriage is flat. This pattern is consistent with the predictions of the model. Of course, there are many other factors that could be contributing to the observed relationship between the ratio to the ideal and marriage, including non-linearities in the incomemarriage relationship. We turn to regression analysis to isolate the effect of relative income.

In Table 5, we examine the relative income hypothesis in a linear probability model. Column I indicates that a man's absolute income is strongly related to his marital status. An additional $\log$ point of income raises the probability of being married by 17 percentage points, holding many individual and metropolitan area characteristics constant. This result is consistent with the large literature suggesting that absolute income is an important predictor of marriage. Column II of Table 5 indicates that,

\footnotetext{
${ }^{20}$ The previous section describes sample restrictions for the black and Hispanic samples. The samples include fewer metropolitan areas and exclude the top and bottom ten percent of the income distributions.

${ }^{21}$ As discussed in the appendix, estimated potential earnings of women increased substantially.
} 
controlling log-linearly for his own income, a man is 4.4 percentage points less likely to be married if his income falls below the marriage ideal.

The theoretical framework implies that is the ratio of income to the ideal that affects marital status. As shown in column III, the ratio of a man's own income to the ideal has a highly significant relationship to marriage below the ideal. The ratio between income and the ideal is also statistically significant for men above the ideal, but the coefficient is much smaller.

The evidence in the first three columns is consistent with the idea that relative income is important, but could also reflect an underlying non-linear relationship between income and marriage. We prefer a more flexible specification. We create 100 dummy variables for each year corresponding to income percentile groups of the national income distribution. ${ }^{22}$ Incorporating the nearly 300 income dummy variables into the model, we find results that are highly consistent with the theoretical predictions. Column IV of Table 5 shows that the ratio to the ideal significantly affects the probability of marriage below the ideal, but not above ideal. In column $\mathrm{V}$, we add 9 dummies indicating the decile rank category in the metropolitan area and the results hold.

We prefer the model in column $\mathrm{V}$ of Table 5 because it is conservative. We flexibly account for both absolute income and metropolitan area rank. The magnitude of the coefficient suggests that moving one's income from the 70 to 80 percent of the marriage ideal, for example, increases the probability of marriage by 2.4 percentage points. In contrast, moving from 120 to 130 percent of the ideal increases marriage by less than 0.1 percentage point, and the effect is statistically indistinguishable from zero. We refer to the model in column $\mathrm{V}$ as our baseline model.

We next allow the effect of the ratio to vary by income decile rank in the metropolitan area (controlling for the direct effect of decile rank and controlling flexibly for absolute income). The results of this analysis are presented in Figure 5. The effect of the ratio to

\footnotetext{
${ }^{22}$ The distribution accounts for cost-of-living differences across metropolitan areas.
} 
the marriage ideal is statistically significant in the second through seventh deciles and peaks in the third decile. As noted above, roughly 70 percent of the sample lies below the marriage ideal, so these results are highly consistent with the model. The absence of an effect for the bottom decile may reflect measurement error and the smaller sample size, or may indicate that the behavior of the bottom decile individuals is not affected by a middle class reference group. ${ }^{23}$

The baseline model is consistent with the theory outlined above, in which we expect the effect of relative income to depend on where an individual stands relative to an ideal. In the appendix, we consider an alternative specification, which considers the relationship between the level of the ideal and marital status, conditional on own income. ${ }^{24}$ Results using this alternative approach are shown in Appendix Table 1. A higher middle class ideal is indeed associated with a lower probability of marriage. After controlling for absolute income (column IV), a 10 percent higher marriage ideal is associated with a 1.1 percentage point lower probability of marriage for those below the ideal (conditional on own income). There is no relationship between the level of the ideal and marital status for those above the ideal. A decile-by-decile analysis shows that the significant effects of a rise in the marriage ideal occur in the fourth and fifth deciles (Appendix Figure 1). Although the results using the alternative specification are largely consistent with those from our baseline model, the baseline specification is more robust and more closely aligned with our theoretical framework. We therefore proceed using the baseline model.

In sum, for young white men, relative income is linked to marital status for those below the middle class marriage ideal, but not for those above the ideal. The association is robust to the inclusion of flexible controls for absolute income and rank. We now consider education-group-specific reference groups.

\footnotetext{
${ }^{23}$ Recall that the bottom five percent of the distribution is dropped from the analysis.

24 This approach is analogous to that used in Luttmer (2005), in which a reference group's average income determines happiness, conditional on own income.
} 


\section{B. Education-Based Reference Groups}

In the baseline model, we define reference groups based on race and ethnicity because these groups appear to be highly relevant for marriage markets. However, marriage norms may be derived based on different reference groups - for example, within education groups or within race/ethnicity and education groups.

In Appendix Table 2, we consider three possible reference groups for the analysis of white men: within race/ethnicity group, within education group, and within race/ethnicity and education group. All reference groups are defined within metropolitan areas. We use the preferred specification which controls flexibly for income and rank. Overall, the race/ethnicity based reference group yields results that most closely align with the predictions of the theoretical framework.

We also examine the reference groups separately for men of different education levels. The baseline reference group (defined by metropolitan area and race/ethnicity) performs well for three of four education groups. The results are consistent with the model for men with less than high school, high school exactly, and some college. The non-collegegraduates appear to base marriage decisions, in part, on how their earnings compare to those of other white workers in the metropolitan area. Using education and race/ethnicity-specific reference groups also generate results that are consistent with the theoretical framework.

For college graduates, the baseline specification offers results that are only marginally consistent with the model. The within-race within-education group specification is an improvement. It appears that white college graduates refer to other white college graduates to define the marriage ideal.

\section{Results for Black and Hispanic Men}

Of particular policy concern is the low rate of marriage among disadvantaged minorities. The first columns of Table 6 repeat the baseline analyses for native non-Hispanic black men. As shown in column I, the ratio of income to the ideal does increase the odds of 
marriage for black men below the ideal. However, to a lesser extent, it also increases the odds of marriage for those above the ideal. Thus, the results are less consistent with the theoretical framework than for the white sample. This is true using both the one-earner and two-earner methodologies (see Appendix Table 4).

It may be the case that black men or couples look beyond the black community as they derive norms about the level of income required for marriage. ${ }^{25}$ We explore three potential reference groups: within race/ethnicity group, within education group, and within race/ethnicity and education group. All three reference groups appear to have some relevance - the slope is higher under the ideal than over the ideal in all three cases. Using the education group as the reference group offers results which have the most significant difference between the under and over coefficients, and is the only specification which has an insignificant effect of the ratio above the ideal as predicted by the model. For black men, the education-based reference group generates results which are most consistent with the theoretical framework, and it is the preferred specification for this sample.

Table 6 also reports results for Hispanic men. For the Hispanic sample, the race/ethnicity specific reference group performs well. Hispanic men exhibit a link between relative income and marriage, but only when their earnings lie below a middle class ideal defined by the earnings of other Hispanic men.

\section{Cohabitation and Fatherhood}

Our theoretical framework is motivated by qualitative work suggesting that some couples defer marriage even when already living together with children. Here we explore whether the relative income effects are evident among cohabiting couples and cohabiting couples with children. Because search considerations are likely to be dampened for

\footnotetext{
${ }^{25}$ Alternatively, it is possible that the $50^{\text {th }}$ percentile is an inappropriate benchmark. Empirical analysis suggests that other benchmarks do not perform significantly better (analysis not shown). We also examine whether the race/ethnicity-based reference group has more salience in more highly segregated metropolitan areas. While we do find some suggestion that this is the case, the results are fragile and we do not present them here.
} 
cohabiting couples, this exercise helps us to isolate the effect of relative income on the marriage decision, conditional on a partnership. ${ }^{26}$ It also allows us examine whether the effect of relative income on marriage appears to stem from declines in cohabitation or declines in men living alone (not co-residing with a partner), and whether relative income drives co-residential fatherhood.

There are several limitations to this analysis. First, for unmarried men, a cohabiting relationship can only be observed in the Census if the man or his partner is the household head. We limit the analysis in this section to men who are household heads or have partners or spouses who are household heads (the household head sample). This introduces selection bias to the extent that the decision to form a separate household is linked to the decision to co-reside with a partner. In addition, the 1980 Census does not distinguish between unmarried partners and roommates. For consistency, we define an unmarried man as cohabiting if he has either a female roommate or an unmarried partner in all three Census years. ${ }^{27}$

Further complications arise in evaluating the decision to have children. A man is listed as having children in the household if he lives with his own children or his step-children; the latter label is endogenous to the marriage decision. Also, it is not possible to observe fatherhood if the man does not live in the same household as is children. Our solution is to describe the man as living with children if he lives with a female partner who has children (regardless of whether they are described as his own). Because non-residential fatherhood is unobservable, the outcome observed is co-residential fatherhood.

Table 7 presents the results of the cohabitation and fatherhood analysis. All regressions use the one-earner methodology and the preferred baseline specification which includes dummy variables for absolute income and decile rank. The reference group is defined by race/ethnicity for the white sample and defined by education for the black sample.

\footnotetext{
${ }^{26}$ Of course, partner search may continue within the context of cohabitation and marriage.

${ }^{27}$ In the 1990 and 2000 Censuses, roughly three quarters of cohabiting men are living with unmarried partners rather than female roommates.
} 
The results for the white household head sample are shown in the first four columns of Panel A of Table 7. Restricting to household heads reduces the white male sample size by about 15 percent. As seen in the first column, the baseline effect of relative income on marriage is substantially weaker than when using the full sample (column V of Table 5), though still significant at the 10 percent level. ${ }^{28}$ The second and third columns of Table 7 suggest that the increase in marriage due to relative income is associated with a commensurate decline in living alone. There is no effect of relative income on unmarried cohabitation in the white sample.

Columns V and VI of Table 7 further restrict the sample to a subsample of couples who live together. Within couples that co-reside (either in cohabitation or marriage), there is no strong effect of relative income on marriage, as shown in column V. Furthermore, there is no effect of relative income on marriage among couples that already co-reside with children (column VII). Taken together, the results for the white sample suggest that relative income affects marital status for couples who would otherwise be living separately. ${ }^{29}$

We also examine the effect of relative income on the fatherhood decision (or, more accurately, the decision to co-reside with children). In columns IV and VI it is evident that the decision to co-reside with kids follows a similar pattern to the pattern for marriage; this is the case whether one considers all men or just those who live with a partner. The ratio of income to the marriage ideal is a strong predictor of co-residential fatherhood below the ideal and much less so above the ideal. In sum, the evidence suggests that reaching the "marriage ideal" jointly spurs co-residence, marriage, and children among white men. This is the case even among less educated white men (results not shown).

\footnotetext{
${ }^{28}$ This decline in effect size may indicate that some of the effect of relative income on marriage arises along with formation of independent households.

${ }^{29}$ These models include controls for race/ethnicity-specific sex ratios in the metropolitan area and dummies indicating decile rank in the local race/ethnicity-specific income distribution. Nevertheless, because nonco-residential partnerships are unobserved, we cannot rule out the possibility that search or marriage market considerations are driving the relationship between relative income and marriage for this group.
} 
The pattern is substantially different for black men, as shown in Panel B of Table 7. About 40 percent of the sample is lost when we restrict to household heads, but the results are qualitatively similar to the preferred specification (reported in column II of Table 6). Panel B of Table 7 indicates that, in contrast to the white sample, the effect of relative income on marriage is associated with a large decline in cohabitation for black men (see column II). Higher relative income is associated with marriage among lowincome black men who would otherwise be cohabiting. Furthermore, among co-residing couples, higher relative income is associated with a higher likelihood of marriage for those below the marriage ideal (see column V). Marriage is linked to relative income considerations even among co-residing couples with children, as shown in column VII.

As is evident in columns IV and VI, the decision to co-reside with children or to have children within the context of a co-residential relationship is not related to the ratio variables for black men. For black men, the decision to live with a partner (in marriage or cohabitation) and to be a co-residential father appears to be largely independent of relative income considerations. However, the decision to marry depends on the ratio of income to the ideal for those below the ideal, even among those already co-residing with a partner and children. The results suggest that relative income affects the decision to marry, conditional on choosing a particular partner.

We perform a similar analysis for Hispanic men (not shown). These men appear to exhibit patterns that fall somewhat in between white and black men. However, the standard errors are large and we cannot say anything definitive.

In sum, relative income is linked to the decision to marry among white and black men. Among white men, the decisions to live with a partner and to have children are also affected by relative income, perhaps because co-residence, marriage, and childbearing are fairly tightly linked. For black men, this is not the case. Relative income does not appear to affect the decision to co-reside or to be a co-resident father. Relative income does, however, affect the decision to marry, even among those living with their partner and children. 


\section{E. Robustness}

In this sub-section we assess the robustness of our results to a variety of specifications. The analysis is presented in Table 8, with the baseline analysis in column I. For the black sample, we present the sensitivity analysis using the education-based reference group. However, results are also consistent with the baseline when using the race/ethnicity-based reference group for the black sample (not shown).

First, we consider the dependent variable. In the main specification individuals are defined as married if they are currently married and living with their spouse. In column II, we use the category "ever married" as the dependent variable. Our model speaks to the decision to marry rather than to the decision to remain married, so it is unsurprising that the results are not substantially changed. ${ }^{30}$ We also see in column III that the divorce decision is unaffected by relative income considerations of the type explored here. ${ }^{31}$

Next, we examine the role of housing prices. In the baseline, we adjust for cost-of-living differences by assuming 0.36 of expenditures are affected by housing prices, as suggested by Albouy (2008). However, it is possible that the adjustment does not accurately reflect differences in cost-of-living, implying that the identified effect could result from absolute rather than relative income. In column IV we try an unadjusted measure of income and in column $\mathrm{V}$ we use an expenditure share of 0.5 . In column VI, we drop the control for the housing price index. None of these alternative approaches to accounting for housing price differentials across metropolitan areas make a substantive difference to the results.

In column VII, we run the regressions without excluding the tails of the income distribution. When the top and bottom five percent of the income distribution are included, the white sample results are muted but retain their significance. We suspect the

\footnotetext{
${ }^{30}$ An exception is that the results for the Hispanic sample are sensitive to the ever-married and married distinction. This might stem from men who live apart from their spouses, who are considered ever married but not married now according to our definitions.

${ }^{31}$ Given that the sample is comprised of young men, divorce is an uncommon outcome. Relative income considerations could affect the divorce decision more generally.
} 
weaker results stem from measurement error and top- and bottom-coding. The results for the black and Hispanic samples are largely unchanged when the tails are included.

The next columns address the issue that rising male wage inequality may induce a longer search period for women in the marriage market, as posited by Loughran (2002) and Gould and Paserman (2003). Following Gould and Paserman (2003), we use the standard deviation of $\log$ real weekly male wages as an index of inequality. Controlling for inequality in column VIII does not change our results. We also try interacting the inequality measure with an indicator for being below the marriage ideal and our results are unchanged, as shown in column IX.

In column $\mathrm{X}$ we include a more extensive set of rank dummies - one for each percentile of the within-race/ethnicity within-metropolitan area income distribution. This does weaken the results for the white sample. The results for the black sample and Hispanic samples retain their significance.

As a final robustness check presented in the table, column XI uses a probit model. Marginal effects are displayed and are quite similar to the baseline coefficients.

We also try additional robustness checks not presented here. We allow the effects of individual age dummies to vary by year. We control for income linearly in a specification which also includes income categories. We randomly split the sample into two sets of metropolitan areas. The results are consistent with the preferred specifications in all cases.

\section{F. Extensions}

In the appendix, we discuss two extensions. First, we incorporate women's earnings into the model. The alternative marriage bars using this approach are shown in Appendix Table 3. The results of the analysis incorporating potential female earnings are similar to the baseline analysis (see Appendix Table 4). Income is a strong predictor of marriage 
when a couple's potential earnings lies below a middle class ideal, and income is less closely tied to marriage above the ideal.

In the appendix we also extend the length of the analysis by incorporating data from the 1\% Public Use Microdata Sample of the 1970 Census. Incorporating the 1970 data requires changing the analysis slightly: the number of metropolitan areas is reduced, income is not adjusted for housing price differences across metropolitan areas, and some control variables are unavailable. Nevertheless, the results are highly consistent with those from the main analysis. The results of the 1970-2000 analysis are reported in Appendix Table 5.

\section{Simulations}

The relationship between relative income and marriage is quite robust. However, it is difficult to gauge the importance of the effects by looking at the coefficients. To what extent do relative income considerations explain the steep decline in marriage rates in recent decades or the roughly 30 percentage point marriage gap between high- and lowincome men? Here we use the models generated using 1970-2000 data to assess the magnitude of relative income effects. ${ }^{32}$

The first simulation uses the 1970-2000 analyses (shown in Appendix Table 5) to predict what would have happened if the ratios of income to ideal income maintained their 1970 values (allowing absolute income to change as it actually did). Within each sample, we calculate the average position above/below the bar and ratio variables for each decile rank in each metropolitan area in 1970. We then predict the probability of marriage assuming those variables maintained their 1970 levels throughout the sample for men in a given decile rank and metropolitan area. The resulting values are reported by income quartile in Table 9.

\footnotetext{
${ }^{32}$ Results are similar if we use the baseline 1980-2000 model from Table 5. However, using the 1970-2000 analysis allows us to examine the importance of relative income in marriage declines since 1970. Note that the 1970 analysis includes fewer metropolitan areas and excludes some controls and adjustments for housing prices. We perform the simulations for the native white and native black samples only.
} 
The simulations suggest that about 3 percentage points of the 30-point decline in white marriage rates since 1970 can be attributed to relative income considerations. The effect is largest in the bottom quartiles, where 12 to 14 percent of the decline in marriage can be explained. The simulations suggest that marriage rates would be about four percentage points higher for low-income white men if relative income maintained its 1970 levels, holding absolute income constant.

For the native non-Hispanic black sample, the simulation uses education-specific reference groups to determine the relevant marriage ideal. Within education groups, relative income did not change much between 1970 and 2000 for black men. Therefore, the holding relative income constant at 1970 levels does little to explain falling marriage rates among blacks. ${ }^{33}$

The second simulation examines the hypothetical impact of eliminating relative income considerations altogether. ${ }^{34}$ In the second simulation, we allow each individual to maintain their position over or under the ideal, but set the relevant ratio variable to a value of one. This thought exercise is equivalent to imagining that each individual sets his ideal income at his actual income, holding his actual income constant.

The simulated marriage rates imply that relative income considerations are an important determinant of marriage. Aggregate rates would be 9-10 percentage points higher for both white and black men in the year 2000 if relative income did not affect the marriage decision; rates for the bottom quartile of men would be 20 percentage points higher. Furthermore, relative income considerations explain more than half of the marriage gap between high- and low- income men in every Census year.

In conclusion, relative income appears to be strongly related to marriage rates. Simulations based on regression models imply that marriage rates would be 20

\footnotetext{
${ }^{33}$ The model using race/ethnicity-specific reference groups implies that black marriage rates would be about 8 percent ( 3 percentage points) higher if relative income was held at 1970 levels.

${ }^{34}$ To calculate a "marriage gap" between high- and low-income men, we subtract the marriage rate of bottom quartile men from the rate of top quartile men, where quartiles are defined within metropolitan areas.
} 
percentage points higher for white and black low-income men if marriage ideals were aligned with actual incomes, holding actual incomes fixed. Declining relative incomes for low-income white men explain 10-15 percent of the decline in marriage since 1970.

\section{Conclusions}

Based on the analysis presented here, we conclude that relative income is an important determinant of the marriage decision. A man's "marriageability" appears to be related not only to his absolute level of income, but to income relative to an ideal level determined by a local reference group. Relative income concerns drive 10-15 percent of the decline in marriage for low income white men, and account for half of the persistent gap in marriage between high- and low-income men.

There are multiple potential explanations for the robust association between relative income and marriage. Here we present one theoretical framework - a model of identity that generates predictions consistent with the empirical patterns. Among black men, relative income predicts marital status even among those who live with partners and children. This result is hard to reconcile with traditional economic models of the marriage decision. The identity model is also corroborated by previous qualitative work.

One possibility we have not explored is that the financial ideal associated with marriage may be endogenous to marriage rates. As marriage becomes more rarefied and the financial gap between married and unmarried couples widens, the marriage ideal may increase. The resulting cycle is difficult to identify empirically, but suggests the role of relative income may be understated here.

Finally, we note that while marriage has been proposed as an anti-poverty measure, our results imply that anti-poverty (or, more precisely, anti-inequality) measures may increase marriage rates. On the other hand, as long as it remains difficult for low-income couples to "keep up with the Joneses," the evidence suggests that these couples are likely to defer marriage until their high financial expectations are reached. 


\section{Appendix}

\section{A. An Alternative Model}

The baseline model is consistent with the theory outlined above, in which we expect the effect of relative income to depend on where an individual stands relative to an ideal. However, it is also possible to examine the effect of the ideal on marriage directly, analogous to the approach used in Luttmer (2005). The alternative model is:

$$
\begin{gathered}
\operatorname{Pr}\left(\text { mar }_{i}\right)=\beta_{1} * \text { under }_{i} * Y_{\text {ideal }}+\beta_{2} *\left(1-\text { under }_{i}\right) * Y_{\text {ideal }}+ \\
\beta_{4} * X_{i}+\gamma_{\text {ycat }}+\alpha_{\text {yrank }}+\sigma_{\text {age }}+\partial_{\text {educyr }}+\theta_{\text {metro }}+\varepsilon_{i}
\end{gathered}
$$

In Appendix Table 1, we use the alternative specification to examine the effect of the marriage ideal on the probability of marriage. A higher middle class ideal is indeed associated with a lower probability of marriage; a 10 percent higher median income is associated with a 1.5 percentage point lower marriage rate. After controlling flexibly for absolute income (see column IV), a 10 percent higher marriage ideal is associated with a 1.1 percentage point lower probability of marriage for those below the ideal. There is no significant effect of the ideal for those above the ideal. Using this alternative model, we cannot identify any significant effects after controlling for decile rank (column V). However, a decile-by-decile analysis (Appendix Figure 1) indicates that there are significant effects of a higher marriage ideal occur in the fourth and fifth deciles. The effect for the bottom decile is wrong-signed. ${ }^{35}$

\section{B. Results by Education Group}

Appendix Table 2 explores results stratified by education group for the white male sample. As is evident from the first column, the specification using a race/ethnicityspecific reference group offers the best fit for all men. The remaining columns stratify results by four education categories - less than high school, high school exactly, some college, and college graduate or more. The race/ethnicity-specific reference group performs well for all categories except college graduates. The marriage decisions of

\footnotetext{
${ }^{35}$ This may be due to measurement error. For example, some of the men in the bottom decile might have low income because they were in school, starting a business, or unemployed in the previous year. High median earnings in an area may be correlated with income at the time of the marriage decision.
} 
white college graduates appear to be responsive to the incomes of other white college graduates - that is, a race/ethnicity and education-specific reference group.

Results for the non-white samples using different reference groups are discussed in the main text. We do not have the statistical power to stratify results by education for the non-white samples.

\section{Incorporating Women's Earnings}

Our theoretical model abstracts from the issue of women's earnings. However, the potential earnings of the couple relative to other couples may be important in the marriage decision. It is challenging to estimate a couple's combined earnings for two reasons. First, in the case of an unmarried man, we often do not know the characteristics of his partner or potential partner. ${ }^{36}$ Second, labor supply is endogenous to the marriage decision. To generate estimates of combined earnings, it is necessary to make strong assumptions about the matching process and about female potential earnings. For the purposes of this exercise, we assume that male earnings are not determined by marital status. ${ }^{37}$

To estimate that potential earnings of men's mates, we use the Census sample of 23-32 year-old women. ${ }^{38}$ We discard women who are married with children on the grounds that their earnings are particularly unlikely to approximate potential earnings. Then, we rank each woman within metropolitan area and race/ethnicity group on the basis of her total real income last year. Finally, we assume positive assortative mating of a particular form: every man is matched to an average woman of his same decile rank in the metropolitan area-race/ethnicity income distribution. ${ }^{39}$ Implicitly, we assume that men are matched to a partner in their own race/ethnicity group. This is a reasonable

\footnotetext{
${ }^{36}$ Men's partners can only be observed if they are living in the same household and one member of the partnership is the head of the household. Furthermore, in 1980, one cannot distinguish an unmarried partner from a female roommate in the data.

${ }^{37}$ A long literature debates whether married men receive a premium in the labor market. See Antonovics and Town (2004) for recent evidence of a causal effect of marriage on wages, for example.

${ }^{38}$ We use a younger group because on average women are younger than their husbands.

${ }^{39}$ Although we control for race/ethnicity specific sex ratios in the empirical analysis, we ignore unbalanced sex ratios for the purposes of our matching algorithm.
} 
approximation for native born whites and native born blacks, though not for native born Hispanics. $^{40}$ The incomes of sample "couples" are constructed using the actual male earnings and the estimated female potential earnings. We drop observations with zero or negative estimated female earnings. ${ }^{41}$

We calculate middle class marriage ideals by combining income of male and female fulltime full-year workers in the reference group. The means of these ideals are shown in Appendix Table 3. They are increasing over time for all three groups, reflecting the rise in female earnings. There is also rising inequality in couples' earnings, reflected in the fact that ratios of income to the ideal are falling for those below the ideal and rising for those above the ideal.

Appendix Table 4 shows the results of the two-earner analysis. All regressions control flexibly for absolute income and metropolitan area rank. Columns I through III display the two-earner results for the sample of white men. The ratio of (estimated) two-earner income to the two-earner marriage ideal is a significant determinant of marriage, and the effect is larger below the ideal. For white men, the race/ethnicity-specific reference group generates results that are most consistent with the model. There is a strong positive relationship between income and marital status below the ideal and a much weaker (though still significant) relationship above the ideal.

As shown in columns IV to VI, the two-earner model is consistent with the theoretical framework for black men as well. As is the case with the one-earner analysis, educationspecific marriage ideals perform well.

For white and black men, the two earner model performs similarly to the one-earner model. However, the two earner model does not perform well for Hispanic men, as seen in the final three columns of Appendix Table 4. Given the large fraction of native

\footnotetext{
${ }^{40}$ Among married native born white men in the sample, 93 to 96 percent are married to native born white women, depending on education group. Among married native born black men, 85 to 94 percent are married to native born black women. Among native born Hispanic men, 36 to 65 percent are married to native born Hispanic women (with another 15 to 17 percent marrying foreign born women).

${ }^{41}$ Dropping these observations makes little difference to the results.
} 
Hispanic men who marry outside their race/ethnicity group, it is likely that imputed female potential earnings are particularly inaccurate for this group.

\section{1970-2000 Analysis}

We extend the baseline analysis to incorporate 1970 data. There are several limitations to the 1970-2000 analysis. First, because local areas are less easily matched in IPUMS Census data prior to 1980 , metropolitan area definitions are less consistent over time. There are also some metropolitan areas which are not available in 1970. Second, reliable housing price data are not available in 1970. Therefore income is not adjusted to reflect differences in the cost of living (except for those arising from general inflation at the national level). Third, data on AFDC benefits are not readily available. This control variable is excluded from the 1970 analysis.

Results for white and black men are shown in Appendix Table 5. The coefficients are similar to those in the baseline 1980-2000 analysis. The ratio of income to the ideal is a strong predictor of marriage below the ideal, but not above the ideal. The preferred ideal is determined by within-race reference groups for white men and by within-education reference groups for black men. Given small sample sizes, we do not perform the 19702000 analysis for the Hispanic sample. 


\section{References}

Akerlof, George A. and Rachel E. Kranton, 2000. "Economics and Identity," Quarterly Journal of Economics, 115(3), 715-753.

Albouy, David, 2008. “Are Big Cities Really Bad Places to Live? Improving Quality of Life Estimates Across Cities," unpublished manuscript.

Antonovics, Kate, and Robert Town, 2004. "Are All the Good Men Married? Uncovering the Sources of the Marital Wage Premium," American Economic Review Papers and Proceedings, 94(2), 317-321.

Becker, Gary S., 1981. A Treatise on the Family. Harvard University Press, Cambridge.

Brown, Christopher and Randall Kesselring, 2003. "Female Headship and the Economic Status of Young Men in the United States, 1977-2001," Journal of Economic Issues, 37 (2), 343-351.

Burstein, Nancy R., 2007. "Economic Influences on Marriage and Divorce," Journal of Policy Analysis and Management, 26(2), 387-429

Card, David, Alexandre Mas, and Jesse Rothstein, 2008. "Tipping and the Dynamics of Segregation," Quarterly Journal of Economics, 123(1), 177-218.

Clark, Andrew E., Paul Frijters, and Michael A. Shields, 2008. "Relative Income, Happiness, and Utility: An Explanation for the Easterlin Paradox and Other Puzzles," Journal of Economic Literature, 46(1), 95-144.

Daly, Mary C., Daniel J. Wilson, and Norman J. Johnson, 2007. "Relative status and well-being: evidence from U.S. suicide deaths," Federal Reserve Bank of San Francisco Working Paper Series: 2007-12.

Denizer, Cevdet, C. Holger, and Yvonne Ying, 2000. "Household Savings in Transition Economies," The World Bank Policy Research Working Paper Series: 2299.

Duesenberry, James S., 1949. Income, Savings, and the Theory of Consumer Behavior, Harvard University Press, Cambridge.

Easterlin, Richard A., 1980. Birth and Fortune: The Impact of Numbers on Personal Welfare, Basic Books, New York.

Edin, Kathryn, 2000. "What Do Low-Income Single Mothers Say about Marriage?," Social Problems, 47(1), 112-133.

Eibner, Christine and William N. Evans, 2005. "Relative Deprivation, Poor Health Habits, and Mortality," Journal of Human Resources, 40(3), 591-620. 
Fischer, Justina A.V and Benno Torgler, 2006. "The Effect of Relative Income Position on Social Capital," Economics Bulletin, 26(4), 1-20.

Gibson-Davis, Christina M., Kathryn Edin, and Sara McLanahan, 2005. "High Hopes But Even Higher Expectations: The Retreat From Marriage Among Low-Income Couples," Journal of Marriage and Family, 67(5), 1301-1312.

Gould, Eric D. and M. Daniele Paserman, 2003. "Waiting for Mr. Right: Rising Inequality and Declining Marriage Rates," Journal of Urban Economics, 53, 257-281.

Kosicki, George, 1987. "A Test of the Relative Income Hypothesis," Southern Economic Journal, 54(2), 422-434.

Lam, David, 1988, "Marriage Markets and Assortative Mating with Household Public Goods: Theoretical Results and Empirical Implications," The Journal of Human Resources, 23(4), 462-487.

Lerman, Robert I., 2002. "Marriage and the Economic Well-being of Children and Familes: A Review of the Literature," Urban Institute Research Report, Urban Institute.

Lichter, Daniel T., Zhenchao Qian, Leanna M. Mellott, 2006. "Marriage or Dissolution?: Union Transitions among Poor Cohabiting," Demography, 43(2), 223-240.

Loughran, David S., 2002. "The Effect of Male Wage inequality on Female Age at First Marriage," The Review of Economics and Statistics, 84(2), 237-250.

Luttmer, Erzo, 2005. "Neighbors as Negatives: Relative Earnings and Well-Being," Quarterly Journal of Economics, 120(3), 960-1002.

Miller, Douglas L. and Christina Paxson, 2006. "Relative Income, Race, and Mortality," Journal of Health Economics, 25(5), 979-1003.

Neumark, David, and Andrew Postlewaite, 1998. "Relative income concerns and the rise in women's employment," Journal of Public Economics, 70, 157-183.

Oppenheimer, Valarie Kincade, Matthijs Kalmijn, and Nelson Lim, 1997. "Men's Career Development and Timing of Marriage in a Period of Rising Inequality," Demography, 34(3), 311-330.

Ruggles, Steven, Matthew Sobek, Trent Alexander, Catherine A. Fitch, Ronald Goeken, Patricia Kelly Hall, Miriam King, and Chad Ronnander, 2008. Integrated Public Use Microdata Series: Version 4.0 [Machine-readable database], Minnesota Population Center.

Stevenson, Betsey, and Justin Wolfers, 2007. "Marriage and Divorce: Changes and Their Driving Forces," Journal of Economic Perspectives, 21(2), 27-52. 
Thorton, Arland, William G. Axinn, and Jay D. Teachman, 1995. "The Influence of School Enrollment and Accumulation on Cohabitiation in Early Adulthood," American Sociological Review, 60(5), 762-774.

Torgler, Benno, and Sascha L. Schmidt, 2007. "What Shapes Player Performance in Soccer? Empirical Findings from a Panel Analysis," Applied Economics, 39(16-18), 2355-2369.

Withers, S. Davies, 1998. "Linking household transitions and housing transitions," Environment and Planning A, 30, 615-630.

Willis, Robert J., 1999. "A Theory of Out-of-Wedlock Childbearing," Journal of Political Economy, 107(6), S33-S64.

Wilson, William Julius, 1987. The Truly Disadvantaged: The City, the Underclass, and Public Policy, University of Chicago Press, Chicago. 
Figure 1a. Marriage Rates By Income,

Native Non-Hispanic White Men Ages 25-34, 1950-2000

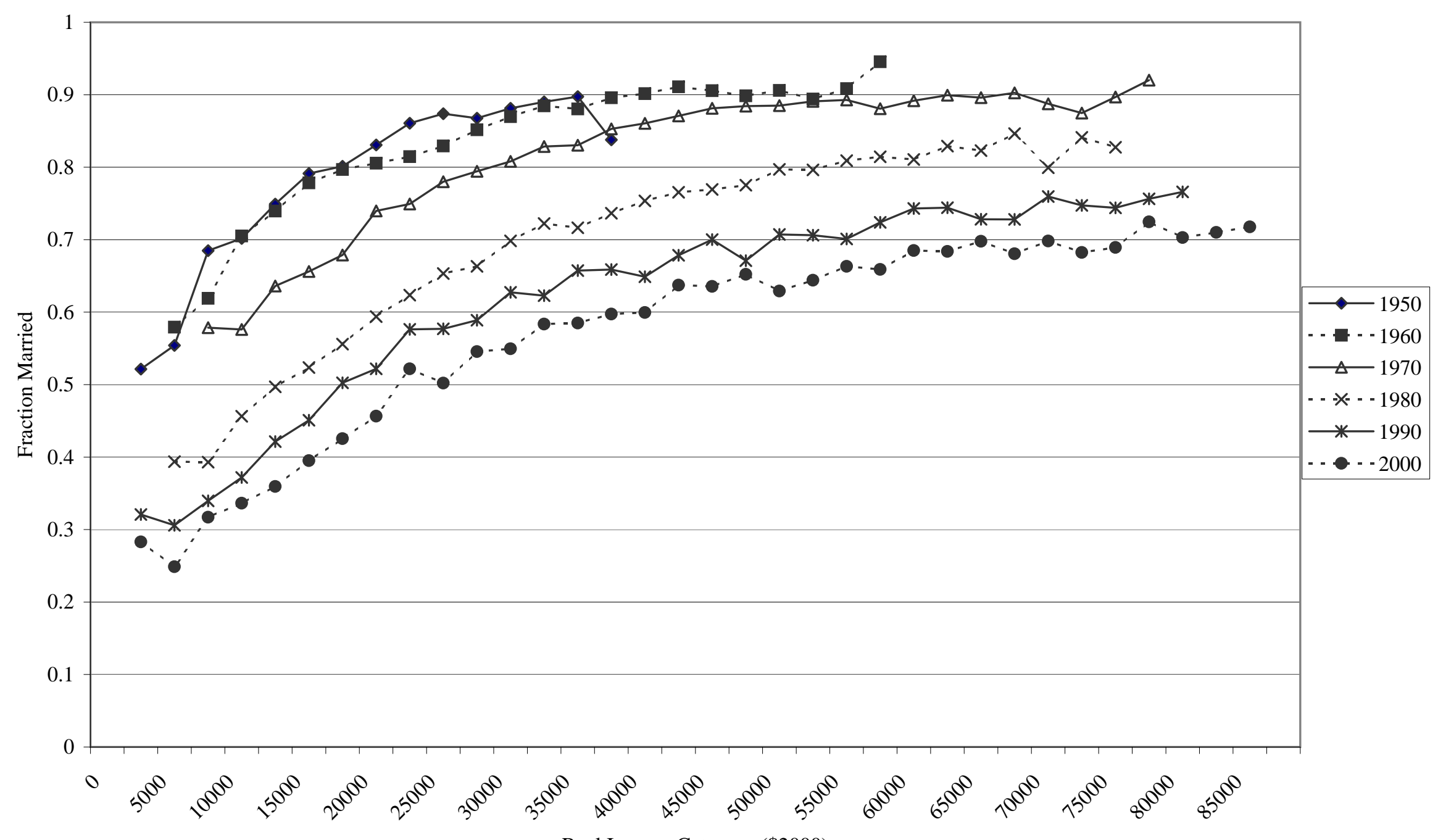

Note: Authors' calculations from U.S. Census. Excludes men living in group quarters and in the top and bottom $5 \%$ of the income distribution. 
Figure 1b. Marriage Rates By Income,

Native Non-Hispanic Black Men Ages 25-34, 1950-2000

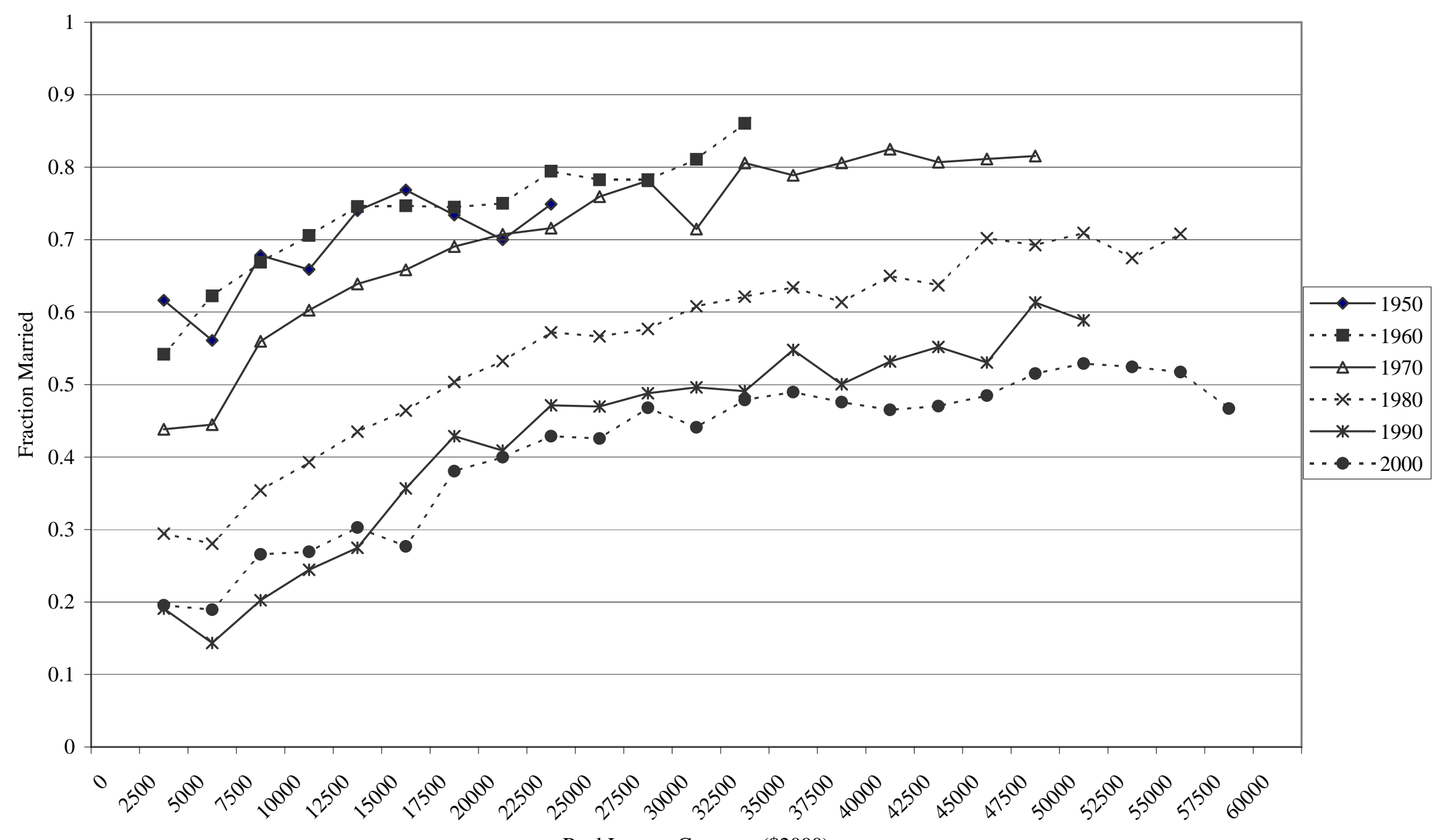

Real Income Category $(\$ 2000)$

Note: Authors' calculations from U.S. Census. Excludes men living in group quarters and in the top and bottom $5 \%$ of the income distribution. 
Figure 1c. Marriage Rates By Income,

Native Hispanic Men Ages 25-34, 1960-2000

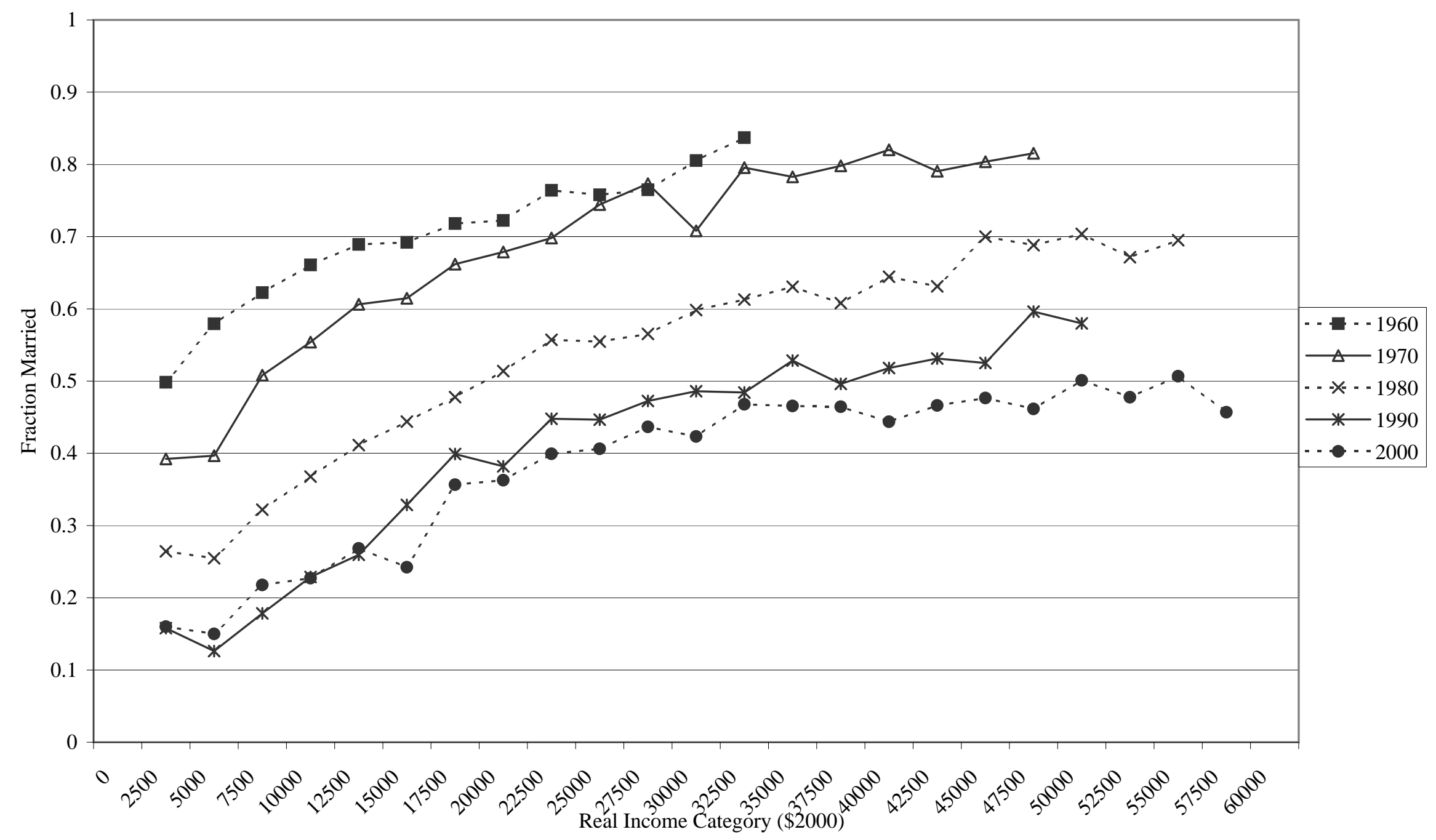

Note: Authors' calculations from U.S. Census. Excludes men living in group quarters and in the top and bottom $5 \%$ of the income distribution. Rates not shown for 1950 due to small sample sizes. 
Table 1. Fraction of 25-to-34-Year-Old Men Married by Income Quartile, 1950-2000

\begin{tabular}{|c|c|c|c|c|c|c|c|c|c|c|}
\hline Year & 1950 & 1960 & 1970 & 1980 & 1990 & 2000 & $\begin{array}{c}\text { Change } \\
1950-2000 \\
\end{array}$ & $\begin{array}{r}\text { \%Decline } \\
1950-2000 \\
\end{array}$ & $\begin{array}{c}\text { Change } \\
1980-2000 \\
\end{array}$ & $\begin{array}{c}\text { \%Decline } \\
1980-2000 \\
\end{array}$ \\
\hline \multicolumn{11}{|l|}{$\begin{array}{c}\text { Native Non-Hispanic White } \\
\text { Quartile }\end{array}$} \\
\hline 1 & 0.59 & 0.67 & 0.65 & 0.49 & 0.39 & 0.34 & -0.25 & 0.42 & -0.15 & 0.31 \\
\hline 2 & 0.78 & 0.83 & 0.82 & 0.68 & 0.57 & 0.51 & -0.27 & 0.34 & -0.16 & 0.24 \\
\hline 3 & 0.85 & 0.88 & 0.87 & 0.75 & 0.65 & 0.60 & -0.25 & 0.30 & -0.16 & 0.21 \\
\hline 4 & 0.87 & 0.90 & 0.89 & 0.81 & 0.72 & 0.67 & -0.20 & 0.23 & -0.14 & 0.17 \\
\hline All & 0.77 & 0.82 & 0.81 & 0.68 & 0.58 & 0.53 & -0.24 & 0.31 & -0.15 & 0.22 \\
\hline \multicolumn{11}{|l|}{$\begin{array}{c}\text { Native Non-Hispanic Black } \\
\text { Quartile }\end{array}$} \\
\hline 1 & 0.53 & 0.51 & 0.50 & 0.27 & 0.14 & 0.16 & -0.36 & 0.69 & -0.11 & 0.39 \\
\hline 2 & 0.63 & 0.71 & 0.70 & 0.47 & 0.25 & 0.29 & -0.34 & 0.54 & -0.18 & 0.38 \\
\hline 3 & 0.73 & 0.76 & 0.77 & 0.59 & 0.44 & 0.43 & -0.30 & 0.41 & -0.16 & 0.27 \\
\hline 4 & 0.74 & 0.81 & 0.81 & 0.67 & 0.54 & 0.50 & -0.24 & 0.32 & -0.17 & 0.25 \\
\hline All & 0.66 & 0.70 & 0.69 & 0.50 & 0.34 & 0.35 & -0.31 & 0.47 & -0.15 & 0.31 \\
\hline \multicolumn{11}{|l|}{$\begin{array}{l}\text { Native Hispanic } \\
\text { Quartile }\end{array}$} \\
\hline 1 & 0.60 & 0.58 & 0.60 & 0.48 & 0.29 & 0.24 & -0.36 & 0.59 & -0.24 & 0.49 \\
\hline 2 & 0.78 & 0.83 & 0.85 & 0.64 & 0.48 & 0.42 & -0.36 & 0.46 & -0.22 & 0.34 \\
\hline 3 & 0.80 & 0.87 & 0.87 & 0.72 & 0.56 & 0.52 & -0.28 & 0.35 & -0.20 & 0.28 \\
\hline 4 & 0.85 & 0.91 & 0.92 & 0.77 & 0.68 & 0.60 & -0.25 & 0.30 & -0.18 & 0.23 \\
\hline All & 0.76 & 0.80 & 0.81 & 0.65 & 0.50 & 0.45 & -0.31 & 0.41 & -0.21 & 0.32 \\
\hline
\end{tabular}

Note: Statistics exclude men living in group quarters. Income quartile refers to standing in national race/ethnicity-specific income distribution in any given year. 


\section{Figure 2. Estimated and Theoretical Ideals for Selected Metropolitan Areas White Male Sample}
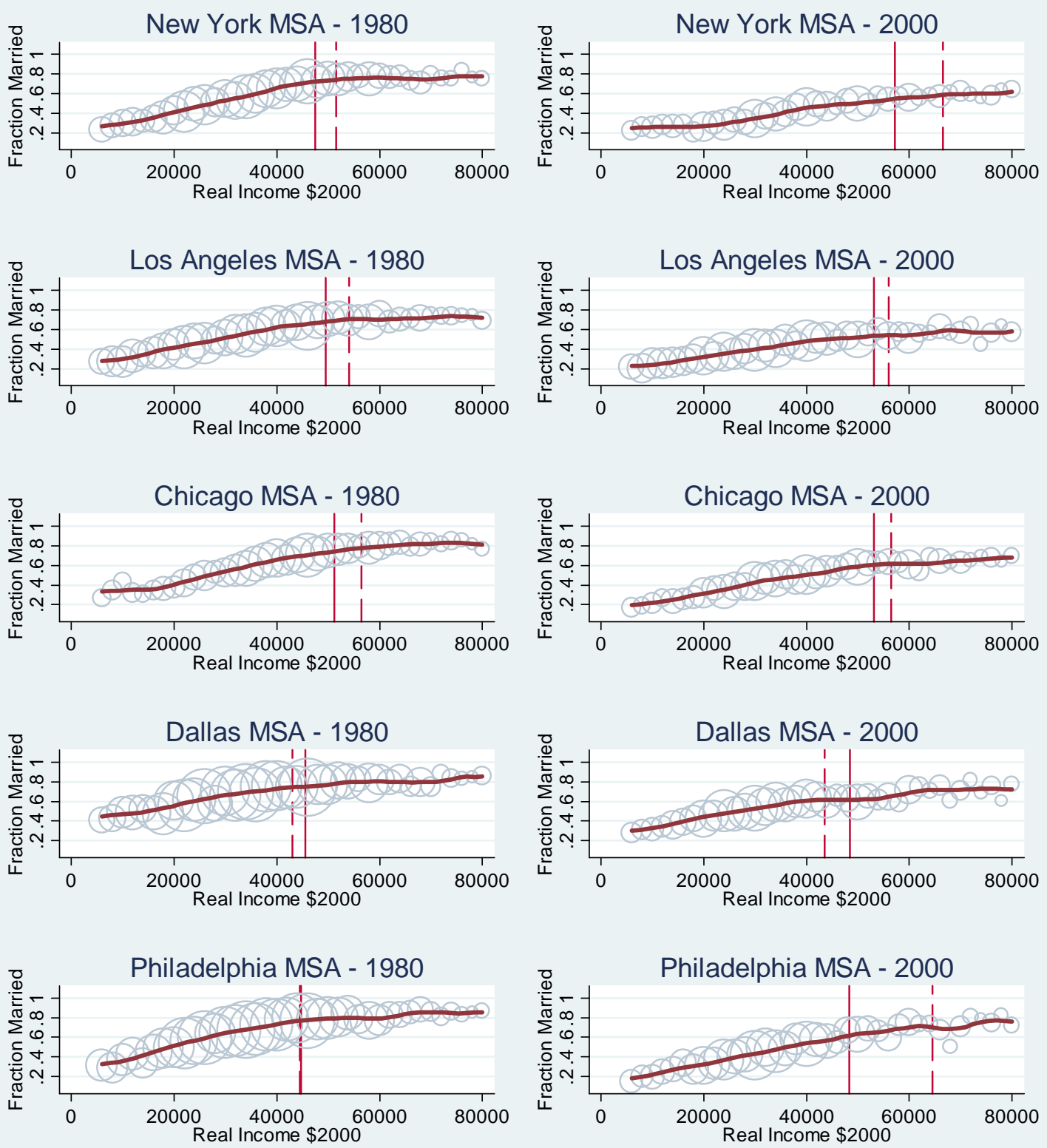

Note: Dashed lines indicate estimated ideals.

Solid lines indicate theoretical middle class ideals. 
Table 2. Marriage Ideals Using Different Reference Groups

\begin{tabular}{|c|c|c|c|c|c|c|c|c|c|}
\hline & \multicolumn{3}{|c|}{ White Sample $(\mathrm{N}=1,159,431)$} & \multicolumn{3}{|c|}{ Black Sample $(\mathrm{N}=142,737)$} & \multicolumn{3}{|c|}{ Hispanic Sample $(\mathrm{N}=67,480)$} \\
\hline & 1980 & 1990 & 2000 & 1980 & 1990 & 2000 & 1980 & 1990 & 2000 \\
\hline \multicolumn{10}{|c|}{ Estimated Ideal (Metro-Year Break in Income-Marriage Relationship Within Race/Ethnicity) } \\
\hline Estimated Ideal Available & 0.99 & 1.00 & 0.98 & 0.75 & 0.75 & 0.69 & 0.83 & 0.82 & 0.82 \\
\hline Estimated Ideal if Available (\$2000) & 41,972 & 43,044 & 43,898 & 34,633 & 32,361 & 34,703 & 35,825 & 37,480 & 33,317 \\
\hline \multicolumn{10}{|c|}{ Baseline Marriage Ideal, (Metro-Year Median FT Male Tot Income Within Race/Ethnicity) } \\
\hline Theoretical Middle Class Ideal (\$2000) & 45,282 & 45,723 & 46,476 & 32,117 & 32,153 & 32,784 & 35,115 & 34,821 & 32,884 \\
\hline Under Ideal & 0.69 & 0.72 & 0.72 & 0.71 & 0.80 & 0.77 & 0.66 & 0.71 & 0.69 \\
\hline Ratio of Income to Ideal if Under & 0.63 & 0.60 & 0.60 & 0.54 & 0.51 & 0.54 & 0.61 & 0.56 & 0.58 \\
\hline Ratio of Income to Ideal if Over & 1.25 & 1.28 & 1.34 & 1.24 & 1.17 & 1.19 & 1.23 & 1.22 & 1.25 \\
\hline \multicolumn{10}{|c|}{ Within-Education Group Marriage Ideal, (Metro-Year Median FT Male Tot Income Within Education) } \\
\hline Theoretical Middle Class Ideal (\$2000) & 45,937 & 44,447 & 45,671 & 41,438 & 39,261 & 39,239 & 40,920 & 38,308 & 37,980 \\
\hline Under Ideal & 0.69 & 0.69 & 0.69 & 0.90 & 0.93 & 0.89 & 0.79 & 0.78 & 0.78 \\
\hline Ratio of Income to Ideal if Under & 0.62 & 0.61 & 0.61 & 0.52 & 0.48 & 0.52 & 0.60 & 0.56 & 0.57 \\
\hline Ratio of Income to Ideal if Over & 1.26 & 1.31 & 1.35 & 1.12 & 1.13 & 1.17 & 1.19 & 1.24 & 1.26 \\
\hline \multicolumn{10}{|c|}{ Within-Education-Race Group Marriage Ideal, (Metro-Year Median FT Male Tot Income Within Education and Race/Ethnicity) } \\
\hline Theoretical Middle Class Ideal (\$2000) & 47,567 & 46,554 & 48,825 & 33,077 & 32,027 & 32,662 & 35,999 & 34,487 & 33,306 \\
\hline Under Ideal & 0.73 & 0.73 & 0.74 & 0.74 & 0.82 & 0.78 & 0.69 & 0.72 & 0.70 \\
\hline Ratio of Income to Ideal if Under & 0.62 & 0.61 & 0.60 & 0.55 & 0.52 & 0.55 & 0.62 & 0.58 & 0.60 \\
\hline Ratio of Income to Ideal if Over & 1.24 & 1.28 & 1.31 & 1.23 & 1.20 & 1.21 & 1.23 & 1.26 & 1.28 \\
\hline
\end{tabular}

Note: Estimated ideal is the point of greatest flattening in income-marriage relationship within metropolitan area-year-race/ethnicity cell. Theoretical ideal is median earnings of fully employed working age men in reference group. See text for details. 


\section{Figure 3. \\ Estimated and Theoretical Ideals Across Metropolitan Areas White Male Sample}
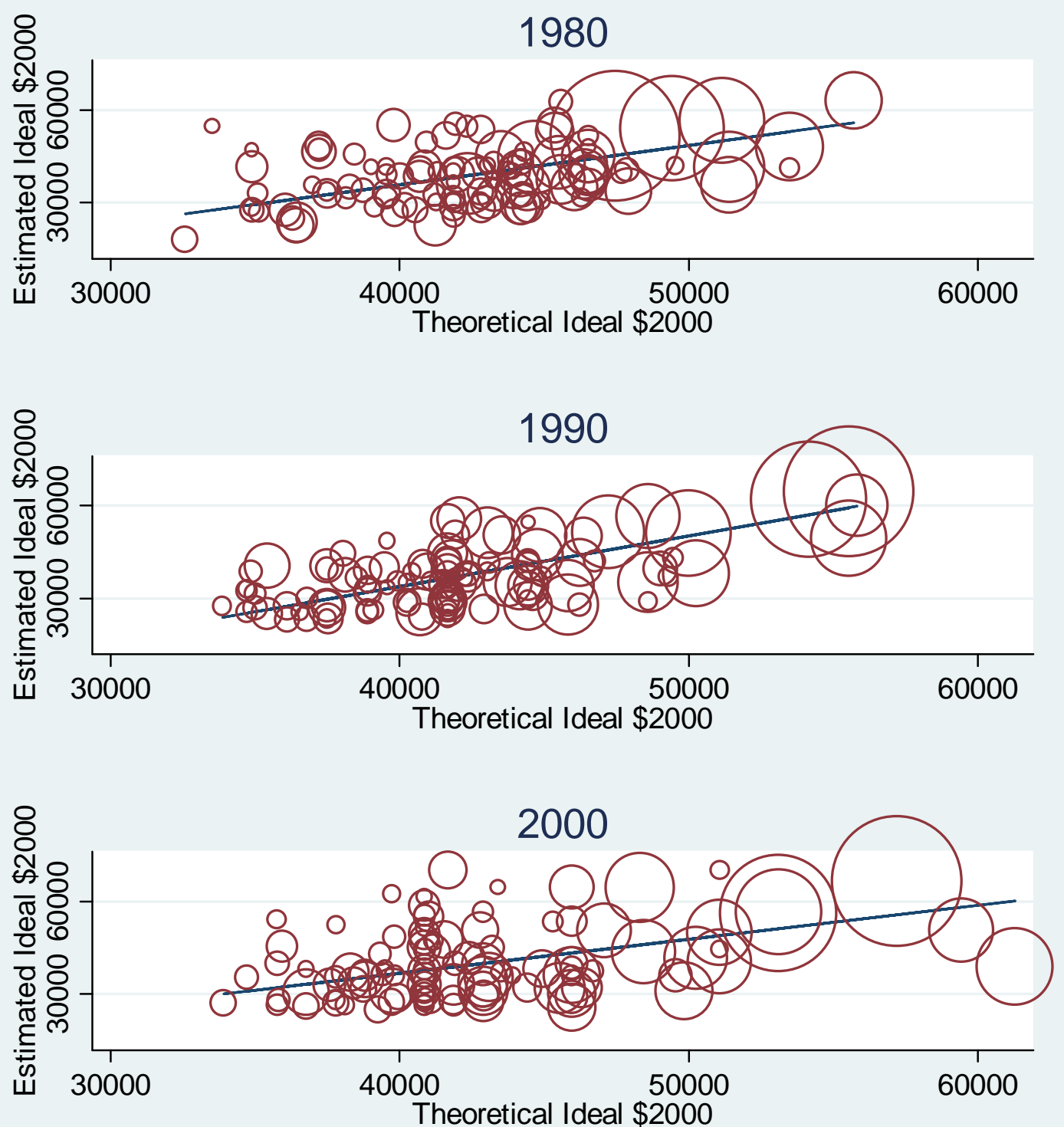

Note: Marker size indicates metropolitan area population. 
Table 3. Determinants of Estimated Marriage Ideals Across Metropolitan Areas

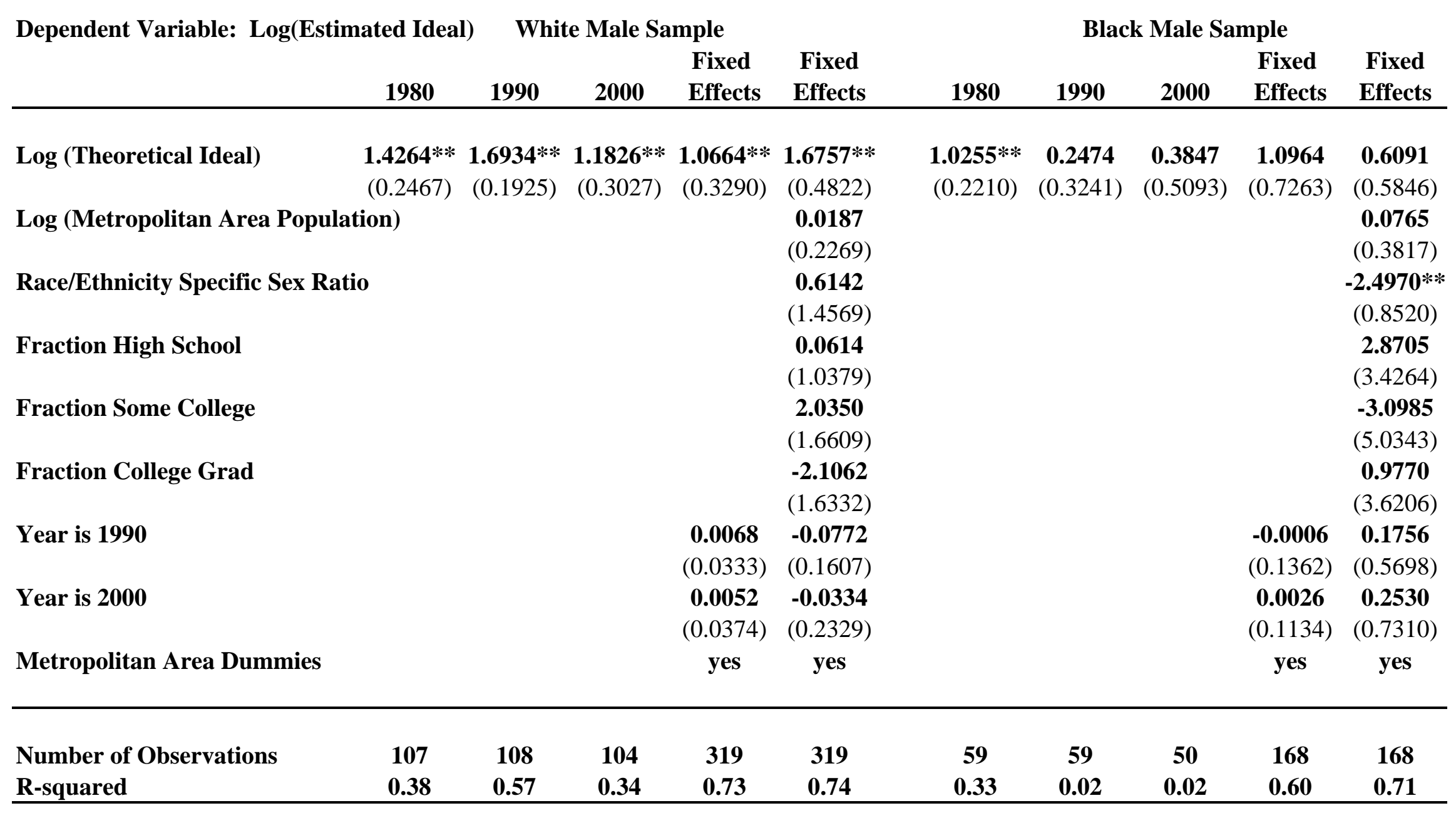

Note: Unit of observation is the metropolitan area-year. Estimated ideal is the point of greatest flattening in income-marriage relationship within metropolitan area-yearrace/ethnicity cell. Theoretical ideal is median earnings of fully employed working age men in reference group. Observations with no estimated ideal are excluded. 
Table 4. Sample Means

\begin{tabular}{|c|c|c|c|c|c|c|c|c|c|}
\hline & \multicolumn{3}{|c|}{ White Sample $(\mathrm{N}=1,159,431)$} & \multicolumn{3}{|c|}{ Black Sample (N=142,737) } & \multicolumn{3}{|c|}{ Hispanic Sample $(\mathrm{N}=67,480)$} \\
\hline & 1980 & 1990 & 2000 & 1980 & 1990 & 2000 & 1980 & 1990 & 2000 \\
\hline \multicolumn{10}{|l|}{ Individual Characteristics } \\
\hline Married (and living with spouse) & 0.65 & 0.56 & 0.50 & 0.49 & 0.34 & 0.33 & 0.63 & 0.48 & 0.43 \\
\hline Married Ever & 0.76 & 0.66 & 0.59 & 0.67 & 0.48 & 0.46 & 0.77 & 0.62 & 0.54 \\
\hline Cohabiting (household head sample) & 0.05 & 0.10 & 0.14 & 0.09 & 0.17 & 0.21 & 0.06 & 0.13 & 0.18 \\
\hline Residential Father (household head sample) & 0.54 & 0.48 & 0.43 & 0.56 & 0.51 & 0.48 & 0.64 & 0.56 & 0.52 \\
\hline Male Total Income, $\$ 2000$ & 36,943 & 36,071 & 37,119 & 23,621 & 20,380 & 22,559 & 28,686 & 26,166 & 25,923 \\
\hline Log(Estimated Female Potential Income), \$2000 & 22,817 & 26,137 & 27,462 & 17,645 & 17,529 & 19,648 & 18,819 & 20,827 & 20,496 \\
\hline Age & 29.30 & 29.54 & 29.68 & 29.11 & 29.37 & 29.55 & 28.95 & 29.08 & 29.10 \\
\hline Employed & 0.92 & 0.93 & 0.92 & 0.80 & 0.80 & 0.78 & 0.88 & 0.88 & 0.83 \\
\hline Employed Full-Time Full-Year & 0.72 & 0.74 & 0.77 & 0.54 & 0.56 & 0.60 & 0.61 & 0.62 & 0.64 \\
\hline High School Exactly & 0.33 & 0.32 & 0.27 & 0.41 & 0.44 & 0.42 & 0.35 & 0.39 & 0.37 \\
\hline Some College & 0.26 & 0.32 & 0.32 & 0.25 & 0.32 & 0.35 & 0.26 & 0.32 & 0.34 \\
\hline College Graduate or More & 0.32 & 0.29 & 0.35 & 0.11 & 0.10 & 0.14 & 0.12 & 0.11 & 0.14 \\
\hline \multicolumn{10}{|l|}{ MSA Characteristics } \\
\hline MSA-Year Race/Ethnicity-Specific Sex Ratio & 1.03 & 1.01 & 1.01 & 1.20 & 1.18 & 1.19 & 1.04 & 1.03 & 1.04 \\
\hline MSA-Year Fraction Black & 0.12 & 0.12 & 0.12 & 0.18 & 0.18 & 0.18 & 0.09 & 0.09 & 0.09 \\
\hline MSA-Year Fraction Native Hispanic & 0.04 & 0.05 & 0.06 & 0.04 & 0.04 & 0.06 & 0.13 & 0.14 & 0.16 \\
\hline MSA-Year Fraction Native Other & 0.01 & 0.02 & 0.03 & 0.01 & 0.01 & 0.03 & 0.02 & 0.03 & 0.04 \\
\hline MSA-Year Fraction Immigrant & 0.08 & 0.10 & 0.13 & 0.09 & 0.11 & 0.14 & 0.13 & 0.18 & 0.23 \\
\hline MSA-Year Fraction Under 18 & 0.28 & 0.25 & 0.26 & 0.28 & 0.25 & 0.26 & 0.28 & 0.26 & 0.27 \\
\hline MSA-Year Fraction Under 65 & 0.89 & 0.88 & 0.88 & 0.90 & 0.89 & 0.89 & 0.90 & 0.89 & 0.89 \\
\hline MSA-Year Fraction High School Exactly & 0.34 & 0.32 & 0.31 & 0.33 & 0.32 & 0.30 & 0.32 & 0.29 & 0.27 \\
\hline MSA-Year Fraction Some College & 0.17 & 0.26 & 0.28 & 0.16 & 0.25 & 0.27 & 0.20 & 0.28 & 0.28 \\
\hline MSA-Year Fraction College Grad & 0.18 & 0.23 & 0.27 & 0.18 & 0.23 & 0.28 & 0.19 & 0.23 & 0.27 \\
\hline MSA-Year Male Emp.-to-Pop. Ratio (ages 18-64) & 0.82 & 0.82 & 0.78 & 0.82 & 0.81 & 0.78 & 0.82 & 0.81 & 0.76 \\
\hline Male Predicted Employment Demand & 0.66 & 0.60 & 0.60 & 0.66 & 0.61 & 0.60 & 0.65 & 0.61 & 0.61 \\
\hline Female Predicted Employment Demand & 0.38 & 0.41 & 0.43 & 0.38 & 0.42 & 0.43 & 0.38 & 0.42 & 0.43 \\
\hline Housing Price Index & 70.74 & 122.85 & 176.18 & 70.25 & 122.27 & 171.96 & 71.74 & 129.70 & 172.85 \\
\hline Real Housing-Price-Adjusted AFDC Benefit, \$2000 & 782.11 & 597.83 & 424.68 & 700.99 & 540.03 & 383.12 & 821.84 & 658.04 & 476.16 \\
\hline Population & 773,233 & 885,234 & 901,754 & 875,741 & 981,934 & $1,009,868$ & $1,065,204$ & $1,355,325$ & $1,493,160$ \\
\hline
\end{tabular}

Notes: White Sample refers to native non-Hispanic white men ages 25-34; Black sample refers to native non-Hispanic black men; Hispanic sample refers to native Hispanic men. Means are for final samples which are restricted to 110, 85, and 47 metropolitan areas, for the white, black and Hispanic samples respectively. White sample excludes top and bottom five percent of the income distribution in each area; Black sample and Hispanic samples exclude top and bottom ten percent. Married Now refers to men married and living with a spouse. Cohabition and residential fatherhood are based on subsamples of household heads and their partners; see text for details. 
Figure 4. Ratio of Income to Ideal and Marriage,

Native Non-Hispanic White Men Ages 25-34

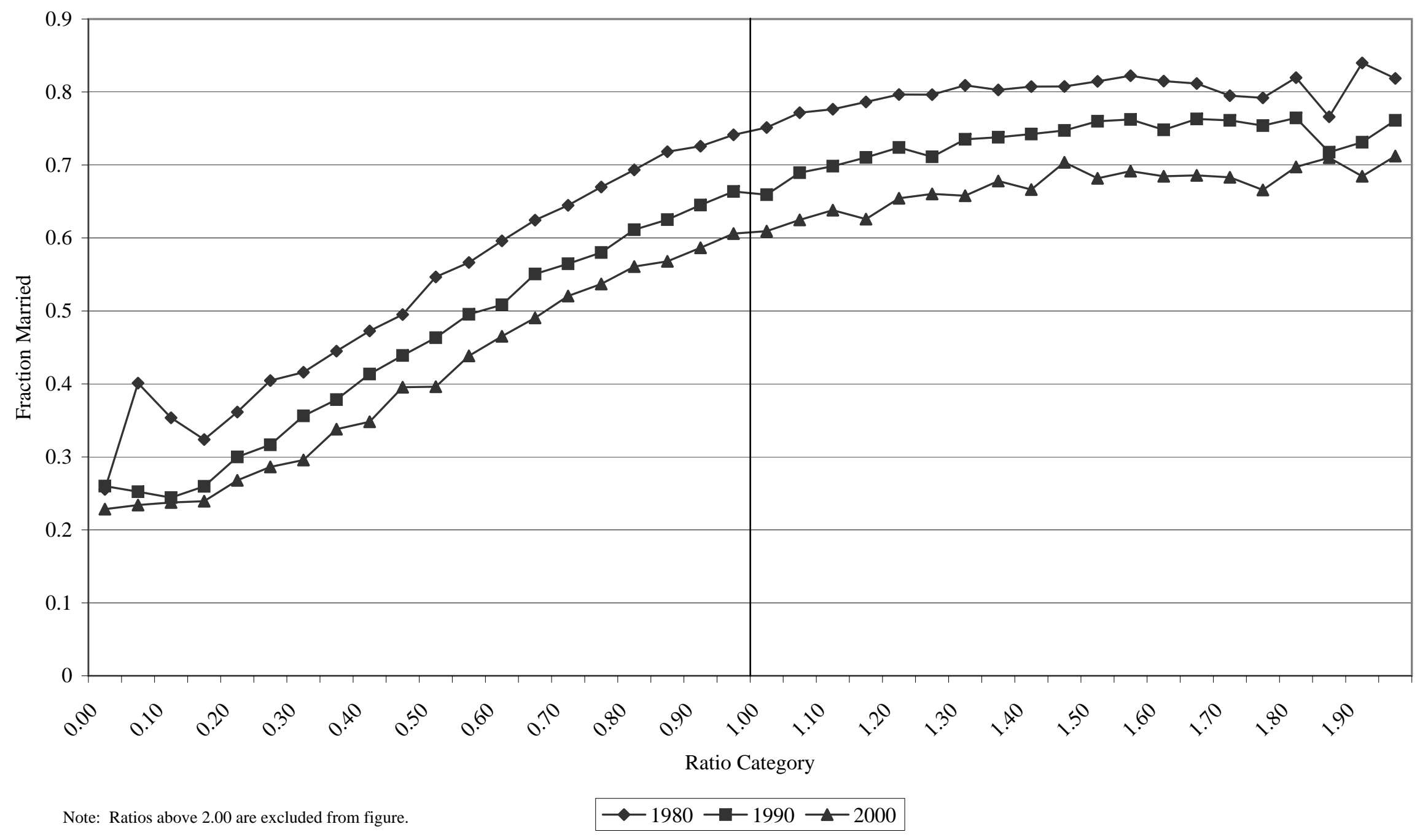


Table 5. Effect of Ratio to Male Marriage Ideal on Marital Status, Native Born Non-Hispanic White Men Ages 25-34

\begin{tabular}{|c|c|c|c|c|c|}
\hline $\begin{array}{l}\text { Dependent Variable: Married } \\
\text { (mean }=0.572)\end{array}$ & $\mathbf{I}$ & II & III & IV & $\mathbf{V}$ \\
\hline Ratio Income/Ideal if Under Marriage Ideal & & & $\begin{array}{c}\mathbf{0 . 4 6 2 0} * * \\
(0.0191)\end{array}$ & $\begin{array}{c}\mathbf{0 . 3 4 6 4 * *} \\
(0.0476)\end{array}$ & $\begin{array}{l}\mathbf{0 . 2 4 0 7 * *} \\
(0.0564)\end{array}$ \\
\hline Ratio Income/Ideal if Over Marriage Ideal & & & $\begin{array}{l}\mathbf{0 . 1 1 2 0} * * \\
(0.0071)\end{array}$ & $\begin{array}{c}\mathbf{0 . 0 3 0 2} \\
(0.0263)\end{array}$ & $\begin{array}{c}\mathbf{0 . 0 0 6 9} \\
(0.0300)\end{array}$ \\
\hline Under Marriage Ideal & & $\begin{array}{c}\mathbf{- 0 . 0 4 3 9 * *} \\
(0.0055)\end{array}$ & $\begin{array}{c}-\mathbf{0 . 3 3 8 0 * *} \\
(0.0160)\end{array}$ & $\begin{array}{c}-\mathbf{0 . 3 0 4 1 * *} \\
(0.0374)\end{array}$ & $\begin{array}{r}\mathbf{- 0 . 2 2 2 9} * * \\
(0.0445)\end{array}$ \\
\hline Log (Real Total Income) & $\begin{array}{c}\mathbf{0 . 1 7 2 7 * *} \\
(0.0048)\end{array}$ & $\begin{array}{c}\mathbf{0 . 1 5 2 2} * * \\
(0.0062)\end{array}$ & $\begin{array}{c}\mathbf{- 0 . 0 2 9 1 * *} \\
(0.0091)\end{array}$ & & \\
\hline Employed & $\begin{array}{c}\mathbf{0 . 0 6 8 3} * * \\
(0.0026)\end{array}$ & $\begin{array}{c}\mathbf{0 . 0 7 2 5} * * \\
(0.0026)\end{array}$ & $\begin{array}{c}\mathbf{0 . 0 7 9 4} * * \\
(0.0027)\end{array}$ & $\begin{array}{c}\mathbf{0 . 0 7 8 8} * * \\
(0.0027)\end{array}$ & $\begin{array}{r}\mathbf{0 . 0 7 8 7} * * \\
(0.0027)\end{array}$ \\
\hline Employed Full Time Full Year & $\begin{array}{c}\mathbf{0 . 0 4 7 3} * * \\
(0.0032)\end{array}$ & $\begin{array}{r}\mathbf{0 . 0 5 0 2} * * \\
(0.0033)\end{array}$ & $\begin{array}{c}\mathbf{0 . 0 4 4 4 * *} \\
(0.0028)\end{array}$ & $\begin{array}{c}\mathbf{0 . 0 4 2 7} * * \\
(0.0029)\end{array}$ & $\begin{array}{r}\mathbf{0 . 0 4 2 6} * * \\
(0.0029)\end{array}$ \\
\hline CMSA Sex Ratio (within race/ethnicity group) & $\begin{array}{c}\mathbf{0 . 4 0 3 7 * *} \\
(0.0973)\end{array}$ & $\begin{array}{c}\mathbf{0 . 4 1 0 0 * *} \\
(0.0940)\end{array}$ & $\begin{array}{c}\mathbf{0 . 4 2 0 0 * *} \\
(0.0768)\end{array}$ & $\begin{array}{c}\mathbf{0 . 4 2 7 3} * * \\
(0.0821)\end{array}$ & $\begin{array}{c}\mathbf{0 . 4 0 2 2} * * \\
(0.0807)\end{array}$ \\
\hline CMSA Housing Price Index & $\begin{array}{c}-\mathbf{0 . 0 0 0 3} * * \\
(0.0001)\end{array}$ & $\begin{array}{c}\mathbf{- 0 . 0 0 0 3} * * \\
(0.0001)\end{array}$ & $\begin{array}{c}-\mathbf{0 . 0 0 0 2} * \\
(0.0001)\end{array}$ & $\begin{array}{c}\mathbf{- 0 . 0 0 0 1} \\
(0.0001)\end{array}$ & $\begin{array}{c}\mathbf{- 0 . 0 0 0 1} \\
(0.0001)\end{array}$ \\
\hline Log (Real Adjusted AFDC Benefits) & $\begin{array}{c}-\mathbf{0 . 0 2 3 6 +} \\
(0.0120)\end{array}$ & $\begin{array}{c}\mathbf{- 0 . 0 2 3 3 +} \\
(0.0118)\end{array}$ & $\begin{array}{c}\mathbf{- 0 . 0 2 4 8 *} \\
(0.0125)\end{array}$ & $\begin{array}{c}-\mathbf{0 . 0 2 8 8} * \\
(0.0121)\end{array}$ & $\begin{array}{c}\mathbf{- 0 . 0 2 5 7 *} \\
(0.0120)\end{array}$ \\
\hline $\begin{array}{l}\text { Decile Rank in CMSA-Race/Eth Group Dummies } \\
\text { Year-Specific Adjusted Income Dummies } \\
\text { Age Dummies } \\
\text { Year*Ed Group Dummies } \\
\text { Additional CMSA controls } \\
\text { CMSA Dummies }\end{array}$ & $\begin{array}{l}\text { yes } \\
\text { yes } \\
\text { yes } \\
\text { yes }\end{array}$ & $\begin{array}{l}\text { yes } \\
\text { yes } \\
\text { yes } \\
\text { yes }\end{array}$ & $\begin{array}{l}\text { yes } \\
\text { yes } \\
\text { yes } \\
\text { yes }\end{array}$ & $\begin{array}{l}\text { yes } \\
\text { yes } \\
\text { yes } \\
\text { yes } \\
\text { yes }\end{array}$ & $\begin{array}{l}\text { yes } \\
\text { yes } \\
\text { yes } \\
\text { yes } \\
\text { yes } \\
\text { yes }\end{array}$ \\
\hline $\begin{array}{l}\text { Number of Observations } \\
\text { Number of CMSA-Year Cells } \\
\text { R-squared }\end{array}$ & $\begin{array}{c}1159431 \\
330 \\
0.13\end{array}$ & $\begin{array}{c}1159431 \\
330 \\
0.13\end{array}$ & $\begin{array}{c}1159431 \\
330 \\
0.13\end{array}$ & $\begin{array}{c}1159431 \\
330 \\
0.13\end{array}$ & $\begin{array}{c}1159431 \\
330 \\
0.13\end{array}$ \\
\hline
\end{tabular}

Notes: Standard errors in parentheses are clustered on CMSA. +, *,** indicate staistical significance at the 10, 5, and 1 percent level respectively. Regression sample excludes top and bottom 5 percent of income distribution in each metro area-year and those not living in households under the 1980 definition. Additional CMSA controls include race/ethnicity distribution in CMSA (fraction native non-Hispanic black, fraction native Hispanic, fraction native non-Hispanic non-white non-black, fraction foreign born), age distribution in CMSA (fraction under 18, fraction under 65), education distribution in CMSA (fraction high school exactly, fraction some college exactly, fraction college graduate or more), predicted employment demand for men, predicted employment demand for women, and log of population. Education Groups include less than high school, high school exactly, some college, and college graduate or more. Marriage Ideal defined as median income of full-time full-year male workers ages 18-64 in the CMSA-year-race/ethincity group. Adjusted income dummies reflect adjustment for cost of living as described in text. 
Figure 5. Effect of Ratio of Income to Ideal on Marriage By Decile, Native Non-Hispanic White Men

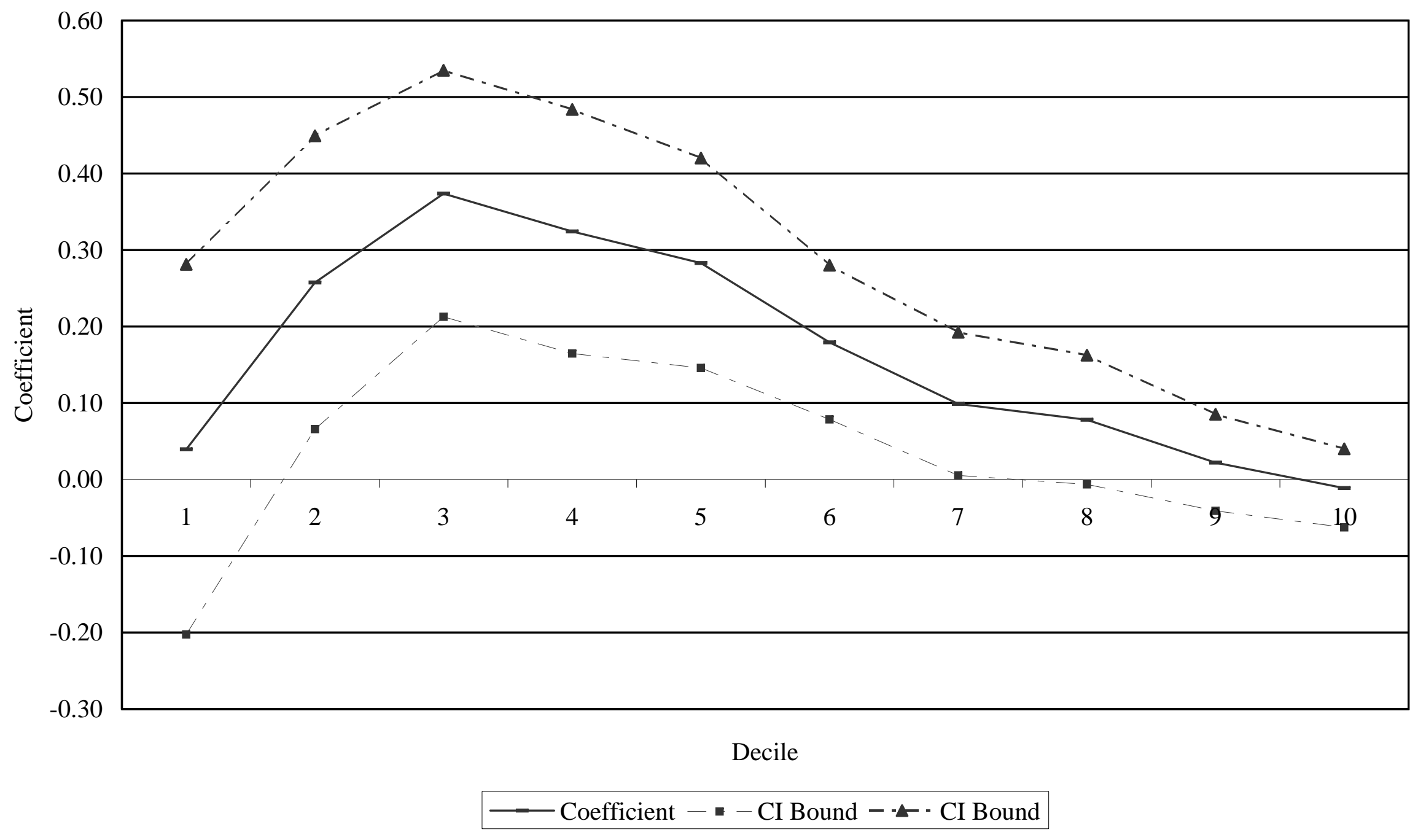


Table 6. Effect of Ratio to Male Marriage Ideal on Marital Status, Black and Hispanic Men, Ages 25-34

\begin{tabular}{|c|c|c|c|c|c|c|}
\hline \multicolumn{7}{|l|}{ Dependent Variable: Married Now } \\
\hline & $\begin{array}{c}\text { Race/Ethnicity } \\
\text { Ref Group } \\
\text { I }\end{array}$ & $\begin{array}{l}\text { Education Ref } \\
\text { Group } \\
\text { II }\end{array}$ & $\begin{array}{c}\text { Race/Ethnicity } \\
\text { and Education } \\
\text { Ref Group } \\
\text { III }\end{array}$ & $\begin{array}{c}\text { Race/Ethnicity } \\
\text { Ref Group } \\
\text { IV }\end{array}$ & $\begin{array}{c}\text { Education Ref } \\
\text { Group } \\
\text { V }\end{array}$ & $\begin{array}{c}\text { Race/Ethnicity } \\
\text { and Education } \\
\text { Ref Group } \\
\text { VI }\end{array}$ \\
\hline Ratio Income/Ideal if Under Marriage Ideal & $\begin{array}{c}\mathbf{0 . 2 9 8 8} * * \\
(0.0640)\end{array}$ & $\begin{array}{c}\mathbf{0 . 2 1 2 8} * * \\
(0.0469)\end{array}$ & $\begin{array}{c}\mathbf{0 . 1 8 6 4} * * \\
(0.0302)\end{array}$ & $\begin{array}{c}\text { 0.2325* } \\
(0.0874)\end{array}$ & $\begin{array}{c}\text { 0.3595** } \\
(0.0518)\end{array}$ & $\begin{array}{c}\mathbf{0 . 2 7 9 0} * * \\
(0.0442)\end{array}$ \\
\hline Ratio Income/Ideal if Over Marriage Ideal & $\begin{array}{c}\mathbf{0 . 1 5 9 6}^{* *} \\
(0.0360)\end{array}$ & $\begin{array}{c}\mathbf{- 0 . 0 1 7 1} \\
(0.0423)\end{array}$ & $\begin{array}{l}\text { 0.0565* } \\
(0.0218)\end{array}$ & $\begin{array}{c}\mathbf{- 0 . 0 0 2 6} \\
(0.0765)\end{array}$ & $\begin{array}{c}\mathbf{0 . 1 7 2 6}^{* *} \\
(0.0256)\end{array}$ & $\begin{array}{c}\mathbf{0 . 1 2 8 2} * * \\
(0.0277)\end{array}$ \\
\hline Under Marriage Ideal & $\begin{array}{c}\mathbf{- 0 . 1 3 1 9 *} \\
(0.0526)\end{array}$ & $\begin{array}{c}\mathbf{- 0 . 2 3 1 0 * *} \\
(0.0468)\end{array}$ & $\begin{array}{c}\mathbf{- 0 . 1 3 7 8} * * \\
(0.0311)\end{array}$ & $\begin{array}{c}\mathbf{- 0 . 2 1 9 8 * *} \\
(0.0731)\end{array}$ & $\begin{array}{c}\mathbf{- 0 . 1 6 3 2 * *} \\
(0.0386)\end{array}$ & $\begin{array}{c}\mathbf{- 0 . 1 5 8 4} * * \\
(0.0470)\end{array}$ \\
\hline $\begin{array}{l}\text { Decile Rank in CMSA-Race/Eth Group Dummies } \\
\text { Year-Specific Adjusted Income Dummies } \\
\text { Age Dummies } \\
\text { Year*Ed Group Dummies } \\
\text { Additional CMSA controls } \\
\text { CMSA Dummies }\end{array}$ & $\begin{array}{l}\text { yes } \\
\text { yes } \\
\text { yes } \\
\text { yes } \\
\text { yes } \\
\text { yes }\end{array}$ & $\begin{array}{l}\text { yes } \\
\text { yes } \\
\text { yes } \\
\text { yes } \\
\text { yes } \\
\text { yes }\end{array}$ & $\begin{array}{l}\text { yes } \\
\text { yes } \\
\text { yes } \\
\text { yes } \\
\text { yes } \\
\text { yes }\end{array}$ & $\begin{array}{l}\text { yes } \\
\text { yes } \\
\text { yes } \\
\text { yes } \\
\text { yes } \\
\text { yes }\end{array}$ & $\begin{array}{l}\text { yes } \\
\text { yes } \\
\text { yes } \\
\text { yes } \\
\text { yes } \\
\text { yes }\end{array}$ & $\begin{array}{l}\text { yes } \\
\text { yes } \\
\text { yes } \\
\text { yes } \\
\text { yes } \\
\text { yes }\end{array}$ \\
\hline $\begin{array}{l}\text { Number of Observations } \\
\text { Number of CMSA-Year Cells } \\
\text { R-squared }\end{array}$ & $\begin{array}{c}142737 \\
255 \\
0.12\end{array}$ & $\begin{array}{c}142737 \\
255 \\
0.12\end{array}$ & $\begin{array}{c}142737 \\
255 \\
0.12\end{array}$ & $\begin{array}{c}67480 \\
123 \\
0.12\end{array}$ & $\begin{array}{c}67480 \\
123 \\
0.12\end{array}$ & $\begin{array}{c}67480 \\
123 \\
0.12\end{array}$ \\
\hline
\end{tabular}

Notes: Standard errors in parentheses are clustered on CMSA. +, *,** indicate staistical significance at the 10,5 , and 1 percent level respectively. Regression sample excludes top and bottom 10 percent of income distribution in each metro area-year and those not living in households under the 1980 definition. Marriage Ideal defined as median earnings of full-time full-year male workers ages 18-64 in the CMSAreference group. See Table 5 and text for more details. 
Table 7. Effect of Ratio to Male Marriage Ideal on Cohabitation and Family Structure

\begin{tabular}{|c|c|c|c|c|c|c|c|}
\hline & I & II & III & IV & $\mathrm{V}$ & VI & VI \\
\hline \multirow[t]{2}{*}{$\begin{array}{l}\text { Panel A. Native Non-Hispanic White Men } \\
\text { (Metro area and race/ethnicity define reference group.) }\end{array}$} & \multicolumn{4}{|c|}{ Full Household Head Sample $(\mathrm{N}=977,732)$} & \multirow{2}{*}{\multicolumn{2}{|c|}{ Coresiding Sample $(\mathrm{N}=762,905)$}} & $\begin{array}{c}\text { Coresiding With Kids } \\
\text { Sample }(\mathrm{N}=490,265)\end{array}$ \\
\hline & & & & Co-residing & & & \\
\hline Dependent Variable: & $\begin{array}{c}\text { Married } \\
(\text { mean }=0.679)\end{array}$ & $\begin{array}{c}\text { Cohabiting } \\
\text { (mean=0.091) }\end{array}$ & $\begin{array}{c}\text { Non-Co-residing } \\
(\text { mean }=0.229)\end{array}$ & $\begin{array}{c}\text { With Kids } \\
\text { (mean }=0.488)\end{array}$ & $\begin{array}{c}\text { Married } \\
(\text { mean }=0.882)\end{array}$ & $\begin{array}{c}\text { With Kids } \\
\text { (mean }=0.663)\end{array}$ & $\begin{array}{c}\text { Married } \\
(\text { mean }=0.963)\end{array}$ \\
\hline Ratio Income/Ideal if Under Marriage Ideal & $\begin{array}{l}\mathbf{0 . 0 9 2 9 +} \\
(0.0498)\end{array}$ & $\begin{array}{c}\mathbf{0 . 0 0 5 1} \\
(0.0319)\end{array}$ & $\begin{array}{l}-\mathbf{0 . 0 9 9 6 *} \\
(0.0414)\end{array}$ & $\begin{array}{c}\text { 0.1770** } \\
(0.0511)\end{array}$ & $\begin{array}{c}-\mathbf{0 . 0 3 6 0} \\
(0.0455)\end{array}$ & $\begin{array}{l}\text { 0.1090* } \\
(0.0548)\end{array}$ & $\begin{array}{c}-\mathbf{0 . 0 1 1 7} \\
(0.0312)\end{array}$ \\
\hline Ratio Income/Ideal if Over Marriage Ideal & $\begin{array}{l}-\mathbf{0 . 0 1 3 2} \\
(0.0322)\end{array}$ & $\begin{array}{l}\text { 0.0397* } \\
(0.0195)\end{array}$ & $\begin{array}{l}-\mathbf{0 . 0 2 7 2} \\
(0.0233)\end{array}$ & $\begin{array}{l}\text { 0.0721* } \\
(0.0304)\end{array}$ & $\begin{array}{l}-\mathbf{0 . 0 8 4 1 *} \\
(0.0329)\end{array}$ & $\begin{array}{c}\mathbf{0 . 0 2 3 7} \\
(0.0268)\end{array}$ & $\begin{array}{l}-\mathbf{0 . 0 2 8 4} \\
(0.0197)\end{array}$ \\
\hline Under Marriage Ideal & $\begin{array}{c}-\mathbf{0 . 0 9 5 4 * *} \\
(0.0349)\end{array}$ & $\begin{array}{c}\mathbf{0 . 0 3 0 2} \\
(0.0235)\end{array}$ & $\begin{array}{l}\text { 0.0658* } \\
(0.0272)\end{array}$ & $\begin{array}{l}-\mathbf{0 . 0 9 9 6 * *} \\
(0.0378)\end{array}$ & $\begin{array}{l}-\mathbf{0 . 0 4 0 4} \\
(0.0306)\end{array}$ & $\begin{array}{r}-\mathbf{0 . 0 8 0 9 +} \\
(0.0411)\end{array}$ & $\begin{array}{l}-\mathbf{0 . 0 1 4 2} \\
(0.0164)\end{array}$ \\
\hline $\begin{array}{l}\text { Panel B. Native Non-Hispanic Black Men } \\
\text { (Metro area and education define reference group.) }\end{array}$ & \multicolumn{4}{|c|}{ Full Household Head Sample $(\mathrm{N}=97,695)$} & \multicolumn{2}{|c|}{ Coresiding Sample $(\mathrm{N}=70,741)$} & $\begin{array}{c}\text { Coresiding With Kids } \\
\text { Sample (N=51,561) }\end{array}$ \\
\hline Dependent Variable: & $\begin{array}{c}\text { Married } \\
(\text { mean }=0.558)\end{array}$ & $\begin{array}{c}\text { Cohabiting } \\
(\text { mean }=0.158)\end{array}$ & $\begin{array}{l}\text { Non-Coresiding } \\
(\text { mean }=0.285)\end{array}$ & $\begin{array}{c}\text { Co-residing } \\
\text { With Kids } \\
(\text { mean }=0.516)\end{array}$ & $\begin{array}{c}\text { Married } \\
(\text { mean }=0.779)\end{array}$ & $\begin{array}{l}\text { Co-residing } \\
\text { With Kids } \\
(\text { mean }=0.721)\end{array}$ & $\begin{array}{c}\text { Married } \\
(\text { mean }=0.871)\end{array}$ \\
\hline Ratio Income/Ideal if Under Marriage Ideal & $\begin{array}{l}\text { 0.1083* } \\
(0.0422)\end{array}$ & $\begin{array}{c}-\mathbf{0 . 1 3 0 9 * *} \\
(0.0277)\end{array}$ & $\begin{array}{c}\mathbf{0 . 0 2 1 7} \\
(0.0444)\end{array}$ & $\begin{array}{c}\mathbf{0 . 0 2 4 0} \\
(0.0398)\end{array}$ & $\begin{array}{c}\text { 0.1094** } \\
(0.0366)\end{array}$ & $\begin{array}{c}\mathbf{0 . 0 0 6 6} \\
(0.0384)\end{array}$ & $\begin{array}{l}\text { 0.0802* } \\
(0.0351)\end{array}$ \\
\hline Ratio Income/Ideal if Over Marriage Ideal & $\begin{array}{l}-\mathbf{0 . 0 0 0 9} \\
(0.0319)\end{array}$ & $\begin{array}{l}-\mathbf{0 . 0 2 9 8} \\
(0.0212)\end{array}$ & $\begin{array}{c}\mathbf{0 . 0 2 8 9} \\
(0.0329)\end{array}$ & $\begin{array}{l}-\mathbf{0 . 0 1 3 7} \\
(0.0289)\end{array}$ & $\begin{array}{l}\mathbf{- 0 . 0 0 9 8} \\
(0.0295)\end{array}$ & $\begin{array}{l}\mathbf{- 0 . 0 2 7 5} \\
(0.0314)\end{array}$ & $\begin{array}{l}-\mathbf{0 . 0 1 1 4} \\
(0.0325)\end{array}$ \\
\hline Under Marriage Ideal & $\begin{array}{c}-\mathbf{0 . 1 1 1 6 * *} \\
(0.0399)\end{array}$ & $\begin{array}{c}\mathbf{0 . 0 9 8 3} * * \\
(0.0251)\end{array}$ & $\begin{array}{c}\mathbf{0 . 0 1 2 3} \\
(0.0423)\end{array}$ & $\begin{array}{l}-\mathbf{- 0 . 0 3 5 4} \\
(0.0450)\end{array}$ & $\begin{array}{c}-\mathbf{0 . 1 1 4 1 * *} \\
(0.0307)\end{array}$ & $\begin{array}{l}-\mathbf{- 0 . 0 2 2 5} \\
(0.0442)\end{array}$ & $\begin{array}{c}-\mathbf{0 . 0 9 9 1 * *} \\
(0.0316)\end{array}$ \\
\hline
\end{tabular}

Notes: Standard errors in parentheses are clustered on CMSA. $+,{ }^{*}, * \star$ indicate statistical significance at the 10,5 , and 1 percent level respectively. Household head sample includes men reported as household heads or partners/roomates of female household heads. Coresiding sample includes members of household head sample who are married or living with a partner or female roommate. Coresiding with kids sample includes members of coresiding sample who have a partner with children living in the household. Each column of a given panel represents a separate regression. Regressions based on preferred specifications and include adjusted income category dummies, declie rank dummies, and all other controls. 
Table 8. Sensitivity Analysis

\begin{tabular}{|c|c|c|c|c|c|c|c|c|c|c|c|}
\hline & I (Baseline) & II & III & IV & $\mathbf{V}$ & VI & VII & VIII & IX & $\mathbf{X}$ & $\mathbf{X I}$ \\
\hline Dependent Variable & Married & Ever Married & Divorced & Married & Married & Married & Married & Married & Married & Married & Married \\
\hline Housing Price Share of COL Adjustment & 0.36 & 0.36 & 0.36 & $\mathbf{0}$ & 0.5 & 0.36 & 0.36 & 0.36 & 0.36 & 0.36 & 0.36 \\
\hline Housing Price Control & Yes & Yes & Yes & Yes & Yes & No & Yes & Yes & Yes & Yes & Yes \\
\hline Tails Excluded & Yes & Yes & Yes & Yes & Yes & Yes & No & Yes & Yes & Yes & Yes \\
\hline Controlling for Inequality & No & No & No & No & No & No & No & Yes & No & Yes & No \\
\hline Controlling for Inequality*Under Ideal & No & No & No & No & No & No & No & No & Yes & No & Yes \\
\hline Number of Rank Dummies & 10 & 10 & 10 & 10 & 10 & 10 & 10 & 10 & 10 & 100 & 10 \\
\hline Econometric Model & OLS & OLS & OLS & OLS & OLS & OLS & OLS & OLS & OLS & OLS & Probit \\
\hline \multicolumn{12}{|l|}{$\begin{array}{l}\text { Panel A. Native Non-Hispanic White Men } \\
\text { (Metro area and race/ethnicity define reference group.) }\end{array}$} \\
\hline Ratio Income/Ideal if Under Marriage Ideal & $\begin{array}{c}\mathbf{0 . 2 4 0 7 * *} \\
(0.0564)\end{array}$ & $\begin{array}{c}\mathbf{0 . 1 9 9 1 * *} \\
(0.0495)\end{array}$ & $\begin{array}{l}\mathbf{- 0 . 0 0 6 7} \\
(0.0109)\end{array}$ & $\begin{array}{c}\mathbf{0 . 2 3 0 5 * *} \\
(0.0601)\end{array}$ & $\begin{array}{c}\mathbf{0 . 2 6 5 7 * *} \\
(0.0561)\end{array}$ & $\begin{array}{c}\mathbf{0 . 2 2 2 8} * * \\
(0.0520)\end{array}$ & $\begin{array}{l}\text { 0.1358* } \\
(0.0539)\end{array}$ & $\begin{array}{c}\mathbf{0 . 2 4 1 8 * *} \\
(0.0559)\end{array}$ & $\begin{array}{c}\mathbf{0 . 2 3 1 7 * *} \\
(0.0551)\end{array}$ & $\begin{array}{c}\mathbf{0 . 0 8 1 4} \\
(0.0647)\end{array}$ & $\begin{array}{r}\mathbf{0 . 1 9 3 3 * *} \\
(0.0518)\end{array}$ \\
\hline Ratio Income/Ideal if Over Marriage Ideal & $\begin{array}{c}\mathbf{0 . 0 0 6 9} \\
(0.0300)\end{array}$ & $\begin{array}{r}\mathbf{- 0 . 0 4 4 0 +} \\
(0.0249)\end{array}$ & $\begin{array}{l}-\mathbf{0 . 0 0 4 8} \\
(0.0062)\end{array}$ & $\begin{array}{c}\mathbf{0 . 0 1 2 3} \\
(0.0354)\end{array}$ & $\begin{array}{c}\mathbf{0 . 0 1 5 0} \\
(0.0282)\end{array}$ & $\begin{array}{l}-\mathbf{0 . 0 0 0 1} \\
(0.0282)\end{array}$ & $\begin{array}{c}-\mathbf{0 . 0 1 4 9 * *} \\
(0.0045)\end{array}$ & $\begin{array}{c}\mathbf{0 . 0 0 7 9} \\
(0.0298)\end{array}$ & $\begin{array}{c}\mathbf{0 . 0 0 5 5} \\
(0.0299)\end{array}$ & $\begin{array}{l}-\mathbf{0 . 0 6 7 0} \\
(0.0544)\end{array}$ & $\begin{array}{c}\mathbf{0 . 0 1 6 0} \\
(0.0360)\end{array}$ \\
\hline Under Marriage Ideal & $\begin{array}{c}-\mathbf{0 . 2 2 2 9} * * \\
(0.0445)\end{array}$ & $\begin{array}{c}-\mathbf{0 . 2 3 3 8 * *} \\
(0.0450)\end{array}$ & $\begin{array}{c}\mathbf{0 . 0 0 3 2} \\
(0.0070)\end{array}$ & $\begin{array}{c}-\mathbf{0 . 2 1 0 9 * *} \\
(0.0416)\end{array}$ & $\begin{array}{c}-\mathbf{0 . 2 3 9 9 * *} \\
(0.0446)\end{array}$ & $\begin{array}{c}-\mathbf{0 . 2 1 2 1} * * \\
(0.0431)\end{array}$ & $\begin{array}{c}-\mathbf{0 . 1 4 2 2} * * \\
(0.0497)\end{array}$ & $\begin{array}{c}-\mathbf{0 . 2 2 3 0 * *} \\
(0.0445)\end{array}$ & $\begin{array}{c}-\mathbf{0 . 2 5 2 9} * * \\
(0.0454)\end{array}$ & $\begin{array}{c}\mathbf{- 0 . 1 3 2 4 *} \\
(0.0515)\end{array}$ & $\begin{array}{c}-\mathbf{0 . 1 6 4 1 * *} \\
(0.0398)\end{array}$ \\
\hline \multicolumn{12}{|l|}{$\begin{array}{l}\text { Panel B. Native Non-Hispanic Black Men } \\
\text { (Metro area and education define reference group.) }\end{array}$} \\
\hline Ratio Income/Ideal if Under Marriage Ideal & $\begin{array}{c}\mathbf{0 . 2 1 2 8 * *} \\
(0.0469)\end{array}$ & $\begin{array}{c}\mathbf{0 . 2 2 0 5 * *} \\
(0.0408)\end{array}$ & $\begin{array}{c}\mathbf{0 . 0 0 0 5} \\
(0.0183)\end{array}$ & $\begin{array}{c}\mathbf{0 . 2 0 6 7 * *} \\
(0.0438)\end{array}$ & $\begin{array}{c}\mathbf{0 . 2 1 2 0} * * \\
(0.0493)\end{array}$ & $\begin{array}{c}\mathbf{0 . 2 1 3 2} * * \\
(0.0465)\end{array}$ & $\begin{array}{c}\mathbf{0 . 2 5 0 5 * *} \\
(0.0375)\end{array}$ & $\begin{array}{c}\mathbf{0 . 2 1 4 3 * *} \\
(0.0467)\end{array}$ & $\begin{array}{c}\mathbf{0 . 2 1 2 3 * *} \\
(0.0469)\end{array}$ & $\begin{array}{r}\mathbf{0 . 1 9 6 8 * *} \\
(0.0412)\end{array}$ & $\begin{array}{r}\mathbf{0 . 2 1 7 3} * * \\
(0.0462)\end{array}$ \\
\hline Ratio Income/Ideal if Over Marriage Ideal & $\begin{array}{l}\mathbf{- 0 . 0 1 7 1} \\
(0.0423)\end{array}$ & $\begin{array}{c}\mathbf{0 . 0 1 9 0} \\
(0.0412)\end{array}$ & $\begin{array}{c}\mathbf{0 . 0 0 9 6} \\
(0.0140)\end{array}$ & $\begin{array}{l}\mathbf{- 0 . 0 1 6 9} \\
(0.0403)\end{array}$ & $\begin{array}{l}-\mathbf{0 . 0 1 9 7} \\
(0.0441)\end{array}$ & $\begin{array}{l}-\mathbf{0 . 0 1 7 0} \\
(0.0422)\end{array}$ & $\begin{array}{r}\mathbf{- 0 . 0 1 1 4 +} \\
(0.0064)\end{array}$ & $\begin{array}{l}\mathbf{- 0 . 0 1 6 4} \\
(0.0423)\end{array}$ & $\begin{array}{l}\mathbf{- 0 . 0 1 7 7} \\
(0.0421)\end{array}$ & $\begin{array}{l}-\mathbf{0 . 0 3 4 0} \\
(0.0424)\end{array}$ & $\begin{array}{l}-\mathbf{0 . 0 0 5 6} \\
(0.0422)\end{array}$ \\
\hline Under Marriage Ideal & $\begin{array}{c}-0.2310 * * \\
(0.0468)\end{array}$ & $\begin{array}{c}-\mathbf{0 . 2 0 3 9 * *} \\
(0.0434)\end{array}$ & $\begin{array}{c}\mathbf{0 . 0 0 9 2} \\
(0.0214)\end{array}$ & $\begin{array}{c}-\mathbf{0 . 2 2 4 6 * *} \\
(0.0454)\end{array}$ & $\begin{array}{c}-\mathbf{0 . 2 3 2 0 * *} \\
(0.0472)\end{array}$ & $\begin{array}{c}-\mathbf{0 . 2 3 1 2 * *} \\
(0.0467)\end{array}$ & $\begin{array}{c}-\mathbf{0 . 2 6 7 0 * *} \\
(0.0331)\end{array}$ & $\begin{array}{c}-\mathbf{0 . 2 3 1 6 * *} \\
(0.0468)\end{array}$ & $\begin{array}{c}-\mathbf{0 . 2 3 9 9 * *} \\
(0.0474)\end{array}$ & $\begin{array}{c}-\mathbf{0 . 2 3 1 3 * *} \\
(0.0477)\end{array}$ & $\begin{array}{c}-\mathbf{0 . 2 3 1 9 * *} \\
(0.0482)\end{array}$ \\
\hline \multicolumn{12}{|l|}{$\begin{array}{l}\text { Panel C. Native Hispanic Men } \\
\text { (Metro area and race/ethnicity define reference group.) }\end{array}$} \\
\hline Ratio Income/Ideal if Under Marriage Ideal & $\begin{array}{l}\text { 0.2325* } \\
(0.0874)\end{array}$ & $\begin{array}{c}\mathbf{0 . 0 9 7 9} \\
(0.1054)\end{array}$ & $\begin{array}{c}\mathbf{0 . 0 0 6 8} \\
(0.0497)\end{array}$ & $\begin{array}{c}\mathbf{0 . 2 6 0 0 * *} \\
(0.0757)\end{array}$ & $\begin{array}{c}\mathbf{0 . 2 8 1 0 * *} \\
(0.0966)\end{array}$ & $\begin{array}{c}\mathbf{0 . 2 3 9 4 * *} \\
(0.0764)\end{array}$ & $\begin{array}{c}\mathbf{0 . 2 3 6 5 * *} \\
(0.0844)\end{array}$ & $\begin{array}{l}\text { 0.2273* } \\
(0.0921)\end{array}$ & $\begin{array}{l}\text { 0.2333* } \\
(0.0871)\end{array}$ & $\begin{array}{l}\mathbf{0 . 1 7 2 2 +} \\
(0.0956)\end{array}$ & $\begin{array}{l}\text { 0.2102* } \\
(0.1004)\end{array}$ \\
\hline Ratio Income/Ideal if Over Marriage Ideal & $\begin{array}{c}\mathbf{- 0 . 0 0 2 6} \\
(0.0765)\end{array}$ & $\begin{array}{c}\mathbf{- 0 . 0 3 3 9} \\
(0.0637)\end{array}$ & $\begin{array}{c}\mathbf{0 . 0 2 5 7} \\
(0.0388)\end{array}$ & $\begin{array}{c}\mathbf{0 . 0 2 0 3} \\
(0.0695)\end{array}$ & $\begin{array}{c}\mathbf{0 . 0 2 1 0} \\
(0.0789)\end{array}$ & $\begin{array}{c}\mathbf{0 . 0 0 0 5} \\
(0.0706)\end{array}$ & $\begin{array}{c}-\mathbf{- 0 . 0 0 3 1} \\
(0.0078)\end{array}$ & $\begin{array}{c}\mathbf{- 0 . 0 0 4 8} \\
(0.0773)\end{array}$ & $\begin{array}{c}\mathbf{- 0 . 0 0 1 1} \\
(0.0753)\end{array}$ & $\begin{array}{c}\mathbf{- 0 . 0 5 8 4} \\
(0.0882)\end{array}$ & $\begin{array}{c}-\mathbf{0 . 0 0 5 9} \\
(0.0879)\end{array}$ \\
\hline Under Marriage Ideal & $\begin{array}{c}-\mathbf{0 . 2 1 9 8} * * \\
(0.0731) \\
\end{array}$ & $\begin{array}{r}-\mathbf{0 . 1 1 4 6} \\
(0.0803) \\
\end{array}$ & $\begin{array}{c}\mathbf{0 . 0 1 8 1} \\
(0.0403) \\
\end{array}$ & $\begin{array}{c}-\mathbf{0 . 2 2 0 6 * *} \\
(0.0572) \\
\end{array}$ & $\begin{array}{c}-\mathbf{0 . 2 4 4 4} * * \\
(0.0744) \\
\end{array}$ & $\begin{array}{c}-\mathbf{0 . 2 2 3 5 * *} \\
(0.0734) \\
\end{array}$ & $\begin{array}{c}-\mathbf{0 . 2 2 7 9} * * \\
(0.0821) \\
\end{array}$ & $\begin{array}{c}-\mathbf{0 . 2 1 7 0 * *} \\
(0.0759) \\
\end{array}$ & $\begin{array}{c}-\mathbf{0 . 2 2 9 0 * *} \\
(0.0839) \\
\end{array}$ & $\begin{array}{c}-\mathbf{- 0 . 2 0 9 0 *} \\
(0.0832) \\
\end{array}$ & $\begin{array}{c}-\mathbf{0 . 1 9 8 9 *} \\
(0.0792) \\
\end{array}$ \\
\hline
\end{tabular}

Notes: Standard errors in parentheses are clustered on CMSA. +, *,** indicate statistical significance at the 10, 5, and 1 percent level respectively. Each column within a panel represents a separate regression. Regressions based on preferred

specifications and include adjusted income category dummies, declie rank dummies, and all other controls. 
Table 9. Simulation Results

\begin{tabular}{|c|c|c|c|c|c|c|c|c|c|c|c|c|c|}
\hline \multicolumn{7}{|c|}{ Native Non-Hispanic White Sample } & \multicolumn{7}{|c|}{ Native Non-Hispanic Black Sample } \\
\hline & $\begin{array}{c}\text { Q1 } \\
\text { Actual }\end{array}$ & $\begin{array}{c}\text { Q2 } \\
\text { Actual }\end{array}$ & $\begin{array}{c}\text { Q3 } \\
\text { Actual }\end{array}$ & $\begin{array}{c}\text { Q4 } \\
\text { Actual }\end{array}$ & $\begin{array}{c}\text { All } \\
\text { Actual }\end{array}$ & Gap & & $\begin{array}{c}\text { Q1 } \\
\text { Actual }\end{array}$ & $\begin{array}{c}\text { Q2 } \\
\text { Actual }\end{array}$ & $\begin{array}{c}\text { Q3 } \\
\text { Actual }\end{array}$ & $\begin{array}{c}\text { Q4 } \\
\text { Actual }\end{array}$ & $\begin{array}{c}\text { All } \\
\text { Actual }\end{array}$ & Gap \\
\hline 1970 & 0.64 & 0.79 & 0.86 & 0.89 & 0.80 & 0.25 & 1970 & 0.54 & 0.69 & 0.77 & 0.82 & 0.70 & 0.29 \\
\hline 1980 & 0.44 & 0.61 & 0.73 & 0.79 & 0.65 & 0.35 & 1980 & 0.29 & 0.42 & 0.56 & 0.64 & 0.48 & 0.35 \\
\hline 1990 & 0.34 & 0.51 & 0.63 & 0.73 & 0.55 & 0.38 & 1990 & 0.18 & 0.24 & 0.40 & 0.50 & 0.34 & 0.32 \\
\hline 2000 & 0.31 & 0.46 & 0.58 & 0.66 & 0.50 & 0.35 & 2000 & 0.19 & 0.26 & 0.38 & 0.47 & 0.33 & 0.28 \\
\hline Change & -0.34 & -0.34 & -0.29 & -0.23 & -0.30 & & Change & -0.35 & -0.43 & -0.39 & -0.35 & -0.37 & \\
\hline \multicolumn{7}{|c|}{$\begin{array}{l}\text { Simulation 1: Relative Income Fixed at } 1970 \text { Levels } \\
\text { Native Non-Hispanic White Sample }\end{array}$} & \multicolumn{6}{|c|}{$\begin{array}{l}\text { Simulation 1: Relative Income Fixed at } 1970 \text { Levels } \\
\text { Native Non-Hispanic Black Sample }\end{array}$} & \\
\hline & $\begin{array}{c}\text { Q1 } \\
\text { Sim1 }\end{array}$ & $\begin{array}{c}\text { Q2 } \\
\text { Sim1 }\end{array}$ & $\begin{array}{c}\text { Q3 } \\
\text { Sim1 }\end{array}$ & $\begin{array}{c}\text { Q4 } \\
\text { Sim1 }\end{array}$ & $\begin{array}{c}\text { All } \\
\text { Sim1 }\end{array}$ & & & $\begin{array}{c}\text { Q1 } \\
\text { Sim1 }\end{array}$ & $\begin{array}{c}\text { Q2 } \\
\text { Sim1 }\end{array}$ & $\begin{array}{c}\text { Q3 } \\
\text { Sim1 }\end{array}$ & $\begin{array}{c}\text { Q4 } \\
\text { Sim1 }\end{array}$ & $\begin{array}{c}\text { All } \\
\text { Sim1 }\end{array}$ & \\
\hline 1970 & 0.64 & 0.79 & 0.86 & 0.89 & 0.80 & & 1970 & 0.54 & 0.69 & 0.77 & 0.82 & 0.70 & \\
\hline 1980 & 0.47 & 0.64 & 0.74 & 0.79 & 0.66 & & 1980 & 0.29 & 0.42 & 0.56 & 0.64 & 0.48 & \\
\hline 1990 & 0.38 & 0.56 & 0.65 & 0.73 & 0.58 & & 1990 & 0.18 & 0.24 & 0.40 & 0.50 & 0.34 & \\
\hline 2000 & 0.35 & 0.50 & 0.60 & 0.66 & 0.53 & & 2000 & 0.19 & 0.26 & 0.38 & 0.47 & 0.33 & \\
\hline Fraction Change Explained & 0.12 & 0.14 & 0.07 & 0.01 & 0.09 & & Fraction Change Explained & 0.00 & 0.00 & 0.00 & 0.00 & 0.00 & \\
\hline \multicolumn{7}{|c|}{$\begin{array}{l}\text { Simulation 2: Relative Income }=1 \\
\text { Native Non-Hispanic White Sample }\end{array}$} & \multicolumn{6}{|c|}{$\begin{array}{l}\text { Simulation 2: Relative Income }=1 \\
\text { Native Non-Hispanic Black Sample }\end{array}$} & Fraction \\
\hline & $\begin{array}{l}\text { Q1 } \\
\text { Sim } 2\end{array}$ & $\begin{array}{c}\text { Q2 } \\
\text { Sim } 2\end{array}$ & $\begin{array}{c}\text { Q3 } \\
\text { Sim } 2\end{array}$ & $\begin{array}{c}\text { Q4 } \\
\text { Sim } 2\end{array}$ & $\begin{array}{c}\text { All } \\
\text { Sim } 2\end{array}$ & $\begin{array}{c}\text { Gap } \\
\text { Explained }\end{array}$ & & $\begin{array}{c}\text { Q1 } \\
\text { Sim } 2\end{array}$ & $\begin{array}{c}\text { Q2 } \\
\operatorname{Sim} 2\end{array}$ & $\begin{array}{c}\text { Q3 } \\
\text { Sim } 2\end{array}$ & $\begin{array}{c}\text { Q4 } \\
\text { Sim } 2\end{array}$ & $\begin{array}{c}\text { All } \\
\text { Sim } 2\end{array}$ & $\begin{array}{c}\text { Gap } \\
\text { Explained }\end{array}$ \\
\hline 1970 & 0.80 & 0.86 & 0.87 & 0.89 & 0.86 & 0.64 & 1970 & 0.70 & 0.78 & 0.83 & 0.84 & 0.79 & 0.49 \\
\hline 1980 & 0.65 & 0.71 & 0.75 & 0.79 & 0.73 & 0.58 & 1980 & 0.50 & 0.55 & 0.63 & 0.66 & 0.59 & 0.55 \\
\hline 1990 & 0.55 & 0.63 & 0.66 & 0.72 & 0.64 & 0.56 & 1990 & 0.39 & 0.40 & 0.49 & 0.53 & 0.45 & 0.55 \\
\hline 2000 & 0.52 & 0.57 & 0.61 & 0.66 & 0.59 & 0.61 & 2000 & 0.39 & 0.40 & 0.46 & 0.50 & 0.43 & 0.62 \\
\hline
\end{tabular}


Appendix Table 1. Effect of Marriage Ideal on Marital Status, Native Born Non-Hispanic White Men Ages 25-34

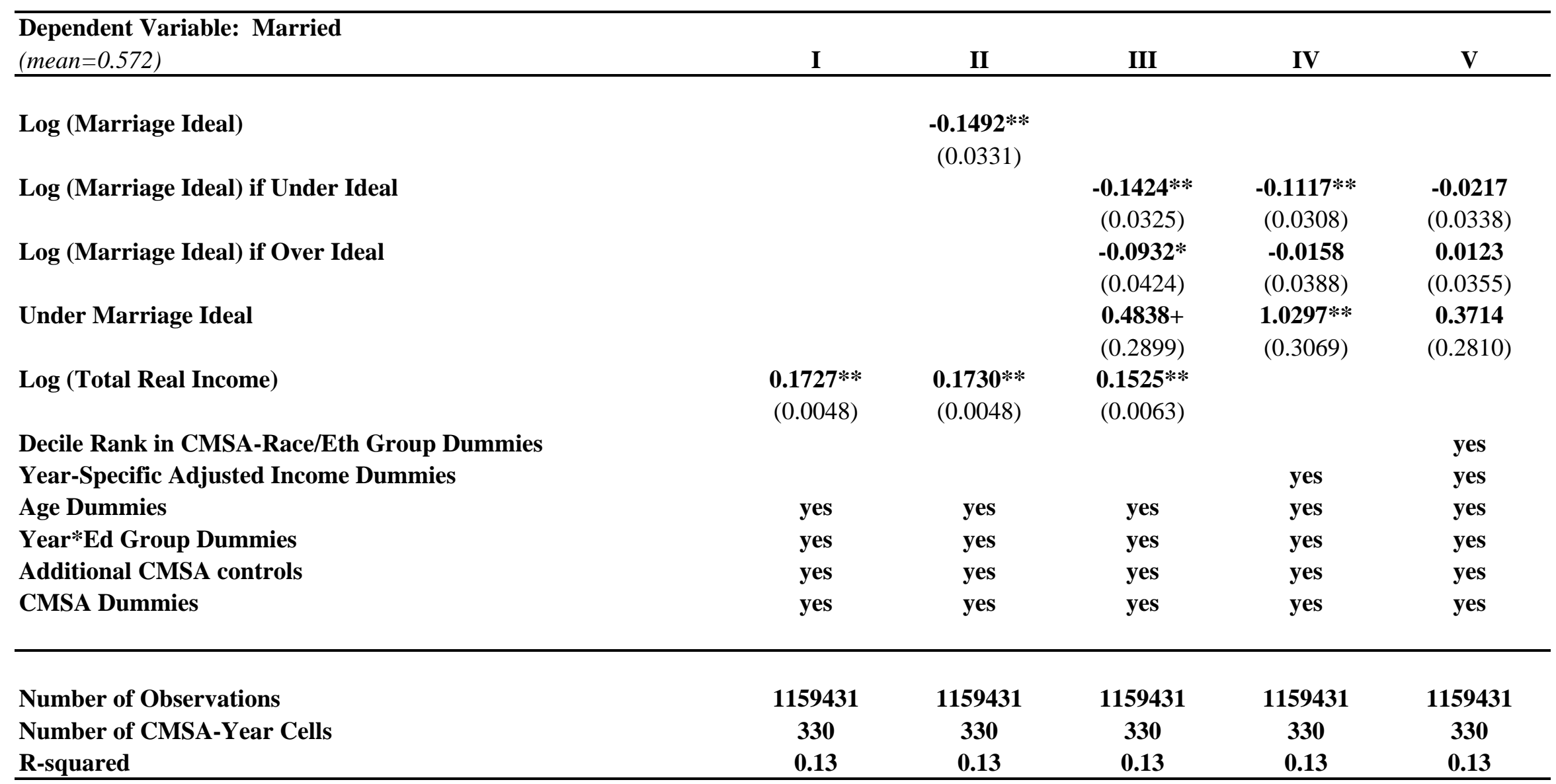

Notes: Standard errors in parentheses are clustered on CMSA. +, *,** indicate staistical significance at the 10, 5, and 1 percent level respectively. Marriage Ideal defined as median earnings of full-time full-year male workers ages 18-64 in the CMSA-year-race/ethincity group. See Table 5 notes and text for additional details. 
Appendix Figure 1. Effect of Ratio of Marriage Ideal on Marriage By Decile, Native Non-Hispanic White Men

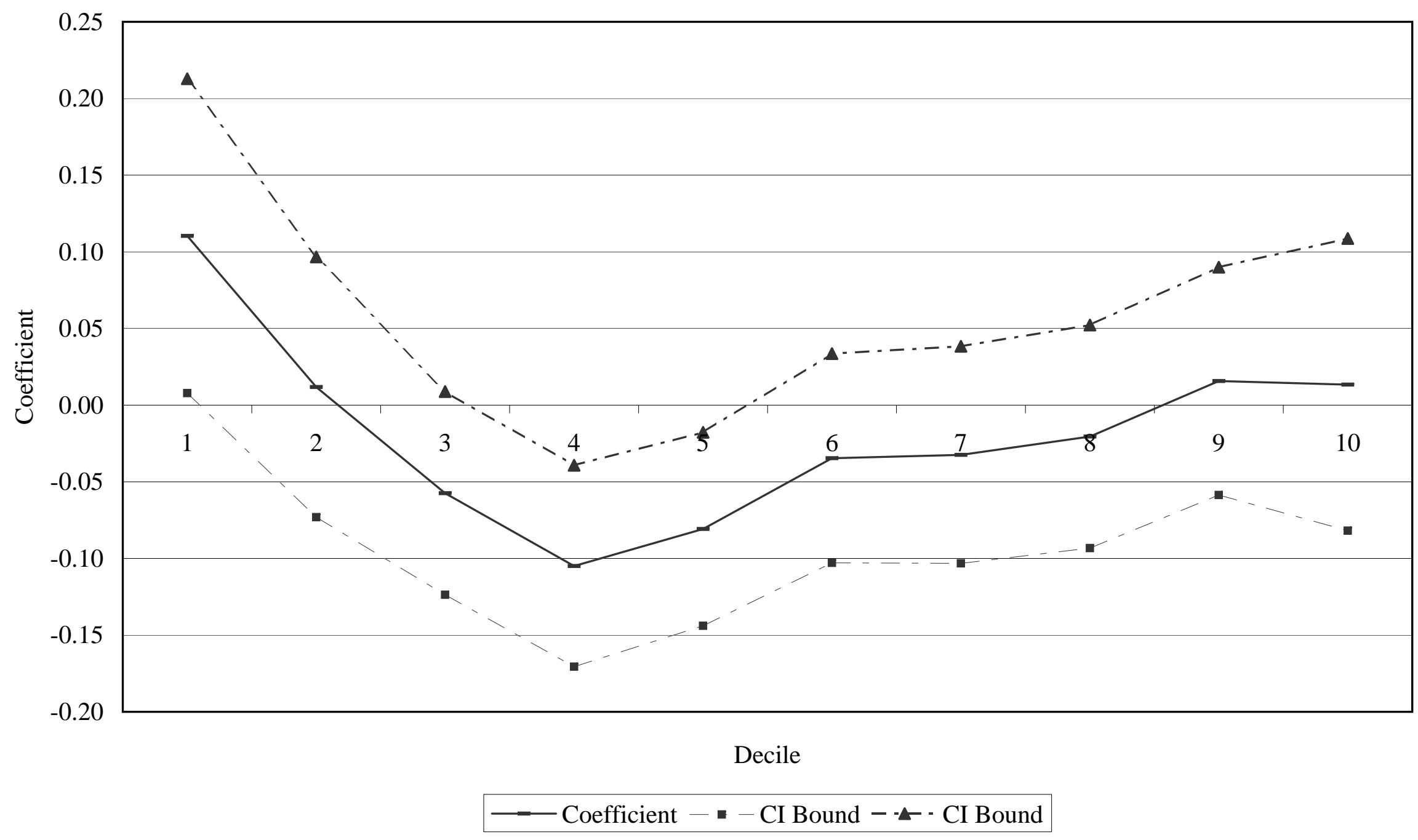


Appendix Table 2. Alternative Bars, By Education Group

Native Born Non-Hispanic White Men

\begin{tabular}{|c|c|c|c|c|c|}
\hline Dependent Variable: Married & All & Less Than HS & HS Exactly & Some College & College Grad \\
\hline \multicolumn{6}{|c|}{ Panel A. Reference Group - Same Race/Ethnicity } \\
\hline Ratio Income/Ideal if Under Marriage Ideal & $\begin{array}{c}\mathbf{0 . 2 4 0 7} * * \\
(0.0564)\end{array}$ & $\begin{array}{l}\mathbf{0 . 2 1 7 2} * \\
(0.1095)\end{array}$ & $\begin{array}{c}\mathbf{0 . 2 0 2 7} * * \\
(0.0708)\end{array}$ & $\begin{array}{c}\mathbf{0 . 2 1 8 7} * * \\
(0.0658)\end{array}$ & $\begin{array}{c}\mathbf{0 . 1 0 4 7 +} \\
(0.0614)\end{array}$ \\
\hline Ratio Income/Ideal if Over Marriage Ideal & $\begin{array}{c}\mathbf{0 . 0 0 6 9} \\
(0.0300)\end{array}$ & $\begin{array}{c}\mathbf{- 0 . 0 8 8 1} \\
(0.0665)\end{array}$ & $\begin{array}{c}-\mathbf{0 . 0 6 9 8 *} \\
(0.0342)\end{array}$ & $\begin{array}{c}\mathbf{- 0 . 0 6 9 5 +} \\
(0.0397)\end{array}$ & $\begin{array}{c}\mathbf{0 . 0 1 2 8} \\
(0.0296)\end{array}$ \\
\hline Under Marriage Ideal & $\begin{array}{c}-\mathbf{0 . 2 2 2 9} * * \\
(0.0445)\end{array}$ & $\begin{array}{c}-\mathbf{0 . 3 0 2 3} * * \\
(0.0885)\end{array}$ & $\begin{array}{c}-\mathbf{0 . 2 5 5 1} * * \\
(0.0550)\end{array}$ & $\begin{array}{c}-\mathbf{0 . 2 8 2 4} * * \\
(0.0607)\end{array}$ & $\begin{array}{c}\mathbf{- 0 . 0 8 0 7} \\
(0.0508)\end{array}$ \\
\hline \multicolumn{6}{|l|}{ Panel B. Reference Group - Same Education } \\
\hline Ratio Income/Ideal if Under Marriage Ideal & $\begin{array}{c}\mathbf{0 . 3 2 4 7} * * \\
(0.0204)\end{array}$ & $\begin{array}{c}\mathbf{0 . 0 7 1 6} \\
(0.0559)\end{array}$ & $\begin{array}{c}\mathbf{0 . 1 8 6 2} * * \\
(0.0598)\end{array}$ & $\begin{array}{l}\mathbf{0 . 1 1 8 5 +} \\
(0.0644)\end{array}$ & $\begin{array}{c}\mathbf{0 . 0 5 3 7} \\
(0.0606)\end{array}$ \\
\hline Ratio Income/Ideal if Over Marriage Ideal & $\begin{array}{c}\mathbf{0 . 1 0 8 2} * * \\
(0.0097)\end{array}$ & $\begin{array}{c}\mathbf{0 . 0 0 2 4} \\
(0.0236)\end{array}$ & $\begin{array}{c}-\mathbf{0 . 0 4 0 5 +} \\
(0.0236)\end{array}$ & $\begin{array}{c}\mathbf{- 0 . 1 1 3 4 * *} \\
(0.0280)\end{array}$ & $\begin{array}{c}\mathbf{- 0 . 0 9 4 6 +} \\
(0.0484)\end{array}$ \\
\hline Under Marriage Ideal & $\begin{array}{c}-\mathbf{0 . 2 1 5 2} * * \\
(0.0133)\end{array}$ & $\begin{array}{c}\mathbf{- 0 . 0 5 4 0} \\
(0.0387)\end{array}$ & $\begin{array}{c}-\mathbf{0 . 2 0 5 7} * * \\
(0.0503)\end{array}$ & $\begin{array}{c}-\mathbf{0 . 2 1 8 8} * * \\
(0.0620)\end{array}$ & $\begin{array}{c}-\mathbf{0 . 1 4 3 6} * * \\
(0.0467)\end{array}$ \\
\hline \multicolumn{6}{|c|}{ Panel C. Reference Group - Same Race/Ethnicity and Education } \\
\hline Ratio Income/Ideal if Under Marriage Ideal & $\begin{array}{c}\mathbf{0 . 3 7 2 3} * * \\
(0.0171)\end{array}$ & $\begin{array}{c}\text { 0.1679* } \\
(0.0671)\end{array}$ & $\begin{array}{c}\mathbf{0 . 2 5 3 7 * *} \\
(0.0645)\end{array}$ & $\begin{array}{l}\mathbf{0 . 1 6 9 0 *} \\
(0.0664)\end{array}$ & $\begin{array}{c}\text { 0.1192* } \\
(0.0542)\end{array}$ \\
\hline Ratio Income/Ideal if Over Marriage Ideal & $\begin{array}{c}\mathbf{0 . 1 2 1 5} * * \\
(0.0113)\end{array}$ & $\begin{array}{c}-\mathbf{0 . 0 4 5 9} \\
(0.0430)\end{array}$ & $\begin{array}{c}-\mathbf{0 . 0 6 5 4} * \\
(0.0292)\end{array}$ & $\begin{array}{c}-\mathbf{0 . 1 2 5 9} * * \\
(0.0305)\end{array}$ & $\begin{array}{c}\mathbf{- 0 . 0 5 6 1} \\
(0.0504)\end{array}$ \\
\hline Under Marriage Ideal & $\begin{array}{c}-\mathbf{0 . 2 4 6 3} * * \\
(0.0135)\end{array}$ & $\begin{array}{c}\mathbf{- 0 . 1 7 9 3} * * \\
(0.0565)\end{array}$ & $\begin{array}{c}\mathbf{- 0 . 2 9 7 7} * * \\
(0.0622)\end{array}$ & $\begin{array}{c}\mathbf{- 0 . 2 8 9 9} * * \\
(0.0670)\end{array}$ & $\begin{array}{c}-\mathbf{0 . 1 6 8 6} * * \\
(0.0395)\end{array}$ \\
\hline
\end{tabular}

Notes: Standard errors in parentheses are clustered on CMSA. +, *,** indicate statistical significance at the 10, 5, and 1 percent level respectively. Each column of a given panel represents a separate regression. Regressions based on preferred specifications and include adjusted income category dummies, declie rank dummies, and all other controls. 
Appendix Table 3. Two-Earner Marriage Ideals Using Different Reference Groups

\begin{tabular}{|c|c|c|c|c|c|c|c|c|c|}
\hline & \multicolumn{3}{|c|}{ White Sample $(\mathrm{N}=1,159,431)$} & \multicolumn{3}{|c|}{ Black Sample $(\mathrm{N}=142,737)$} & \multicolumn{3}{|c|}{ Hispanic Sample $(\mathrm{N}=67,480)$} \\
\hline & 1980 & 1990 & 2000 & 1980 & 1990 & 2000 & 1980 & 1990 & 2000 \\
\hline \multicolumn{10}{|c|}{ Baseline Two-Earner Marriage Ideal, (Metro-Year Median FT Combined Tot Income Within Race/Ethnicity) } \\
\hline Marriage Ideal (\$2000) & 70,849 & 75,713 & 79,469 & 55,306 & 58,370 & 60,897 & 57,546 & 60,997 & 60,036 \\
\hline Under Ideal & 0.66 & 0.70 & 0.72 & 0.70 & 0.81 & 0.79 & 0.65 & 0.71 & 0.73 \\
\hline Ratio of Income to Ideal if Under & 0.63 & 0.61 & 0.61 & 0.56 & 0.54 & 0.57 & 0.62 & 0.60 & 0.60 \\
\hline Ratio of Income to Ideal if Over & 1.27 & 1.30 & 1.34 & 1.22 & 1.17 & 1.18 & 1.22 & 1.22 & 1.24 \\
\hline \multicolumn{10}{|c|}{ Within-Education Group Two-Earner Marriage Ideal, (Metro-Year Median FT CombinedTot Income Within Education) } \\
\hline Marriage Ideal (\$2000) & 73,307 & 74,681 & 78,466 & 66,321 & 66,277 & 67,888 & 65,983 & 65,902 & 66,815 \\
\hline Under Ideal & 0.68 & 0.68 & 0.69 & 0.86 & 0.90 & 0.86 & 0.79 & 0.77 & 0.79 \\
\hline Ratio of Income to Ideal if Under & 0.63 & 0.63 & 0.62 & 0.54 & 0.52 & 0.55 & 0.61 & 0.59 & 0.59 \\
\hline Ratio of Income to Ideal if Over & 1.27 & 1.32 & 1.35 & 1.14 & 1.15 & 1.17 & 1.19 & 1.24 & 1.26 \\
\hline \multicolumn{10}{|c|}{ Within-Education-Race Group Two-Earner Marriage Ideal, (Metro-Year Median FT CombinedTot Income Within Education and Race/Ethnicity) } \\
\hline Marriage Ideal $(\$ 2000)$ & 75,327 & 77,685 & 83,078 & 56,932 & 57,412 & 59,717 & 59,499 & 60,742 & 59,902 \\
\hline Under Ideal & 0.71 & 0.71 & 0.74 & 0.74 & 0.81 & 0.79 & 0.69 & 0.72 & 0.72 \\
\hline Ratio of Income to Ideal if Under & 0.63 & 0.62 & 0.61 & 0.57 & 0.55 & 0.58 & 0.63 & 0.61 & 0.61 \\
\hline Ratio of Income to Ideal if Over & 1.25 & 1.29 & 1.31 & 1.23 & 1.20 & 1.22 & 1.22 & 1.25 & 1.27 \\
\hline
\end{tabular}

Note: Marriage ideal refers to income of fully employed 18-64 men plus income of fully employed 18-64 women in relevant reference group. See appendix text for additional details. 
Appendix Table 4. Two Earner Model

\begin{tabular}{|c|c|c|c|c|c|c|c|c|c|}
\hline & \multicolumn{6}{|c|}{ Dependent Variable: Married } & & & \\
\hline & $\begin{array}{c}\text { Race/Ethnicity } \\
\text { Based } \\
\text { Reference } \\
\text { Groups } \\
\text { I } \\
\end{array}$ & $\begin{array}{l}\text { Education } \\
\text { Based } \\
\text { Reference } \\
\text { Groups } \\
\text { II } \\
\end{array}$ & $\begin{array}{c}\text { Race/Ethnicity } \\
\text { and Education } \\
\text { Based } \\
\text { Reference } \\
\text { Groups } \\
\text { III } \\
\end{array}$ & $\begin{array}{c}\text { Race/Ethnicity } \\
\text { Based } \\
\text { Reference } \\
\text { Groups } \\
\text { IV } \\
\end{array}$ & $\begin{array}{c}\text { Education } \\
\text { Based } \\
\text { Reference } \\
\text { Groups } \\
\text { V } \\
\end{array}$ & $\begin{array}{c}\text { Race/Ethnicity } \\
\text { and Education } \\
\text { Based } \\
\text { Reference } \\
\text { Groups } \\
\text { VI } \\
\end{array}$ & $\begin{array}{c}\text { Race/Ethnicity } \\
\text { Based } \\
\text { Reference } \\
\text { Groups } \\
\text { VII } \\
\end{array}$ & $\begin{array}{c}\text { Education } \\
\text { Based } \\
\text { Reference } \\
\text { Groups } \\
\text { VIII } \\
\end{array}$ & $\begin{array}{c}\text { Race/Ethnicity } \\
\text { and Education } \\
\text { Based } \\
\text { Reference } \\
\text { Groups } \\
\text { IX } \\
\end{array}$ \\
\hline Ratio Income/Ideal if Under Marriage Ideal & $\begin{array}{c}\mathbf{0 . 3 6 4 5} * * \\
(0.0637)\end{array}$ & $\begin{array}{c}\mathbf{0 . 3 4 7 5 * *} \\
(0.0233)\end{array}$ & $\begin{array}{c}\mathbf{0 . 4 0 7 4} * * \\
(0.0179)\end{array}$ & $\begin{array}{c}\mathbf{0 . 2 2 7 0}^{* *} \\
(0.0470)\end{array}$ & $\begin{array}{c}\mathbf{0 . 1 8 0 8}^{* *} * \\
(0.0371)\end{array}$ & $\begin{array}{c}\mathbf{0 . 1 4 1 8}^{* *} \\
(0.0318)\end{array}$ & $\begin{array}{c}\mathbf{0 . 0 6 5 3} \\
(0.0867)\end{array}$ & $\begin{array}{c}\mathbf{0 . 2 9 4 0} * * \\
(0.0487)\end{array}$ & $\begin{array}{c}\mathbf{0 . 2 5 3 1} * * \\
(0.0534)\end{array}$ \\
\hline Ratio Income/Ideal if Over Marriage Ideal & $\begin{array}{l}\text { 0.0670* } \\
(0.0338)\end{array}$ & $\begin{array}{c}\mathbf{0 . 1 2 5 4} * * \\
(0.0116)\end{array}$ & $\begin{array}{c}\mathbf{0 . 1 4 9 1}^{* *} \\
(0.0106)\end{array}$ & $\begin{array}{c}\mathbf{0 . 1 6 4 6 * *} \\
(0.0392)\end{array}$ & $\begin{array}{c}-\mathbf{0 . 0 0 6 0} \\
(0.0296)\end{array}$ & $\begin{array}{l}\mathbf{0 . 0 3 6 3 +} \\
(0.0216)\end{array}$ & $\begin{array}{c}-\mathbf{0 . 0 7 1 7} \\
(0.0980)\end{array}$ & $\begin{array}{c}\mathbf{0 . 1 5 6 9 * *} \\
(0.0289)\end{array}$ & $\begin{array}{c}\mathbf{0 . 1 3 9 9 * *} \\
(0.0319)\end{array}$ \\
\hline Under Marriage Ideal & $\begin{array}{c}-\mathbf{- 0 . 2 9 4 8 * *} \\
(0.0483)\end{array}$ & $\begin{array}{c}-\mathbf{- 0 . 2 2 5 6 * *} \\
(0.0141)\end{array}$ & $\begin{array}{c}-\mathbf{- 0 . 2 5 7 9} * * \\
(0.0130)\end{array}$ & $\begin{array}{c}\mathbf{- 0 . 0 7 3 3} \\
(0.0474)\end{array}$ & $\begin{array}{c}-\mathbf{- 0 . 1 8 4 6 * *} \\
(0.0424)\end{array}$ & $\begin{array}{c}-\mathbf{- 0 . 1 1 9 6 * *} \\
(0.0284)\end{array}$ & $\begin{array}{c}\mathbf{- 0 . 1 5 7 4} \\
(0.1008)\end{array}$ & $\begin{array}{c}-\mathbf{- 0 . 1 3 1 3} * * \\
(0.0326)\end{array}$ & $\begin{array}{c}-\mathbf{- 0 . 1 2 6 0 *} \\
(0.0478)\end{array}$ \\
\hline Decile Rank in CMSA-Race/Eth Group Dummies & yes & yes & yes & yes & yes & yes & yes & yes & yes \\
\hline Year-Specific Adjusted Income Dummies & yes & yes & yes & yes & yes & yes & yes & yes & yes \\
\hline Age Dummies & yes & yes & yes & yes & yes & yes & yes & yes & yes \\
\hline Year*Ed Group Dummies & yes & yes & yes & yes & yes & yes & yes & yes & yes \\
\hline Additional CMSA controls & yes & yes & yes & yes & yes & yes & yes & yes & yes \\
\hline CMSA Dummies & yes & yes & yes & yes & yes & yes & yes & yes & yes \\
\hline Number of Observations & 1156094 & 1156094 & 1156094 & 142405 & 142405 & 142405 & 66929 & 66929 & 66929 \\
\hline Number of CMSA-Year Cells & 330 & 330 & 330 & 255 & 255 & 255 & 123 & 123 & 123 \\
\hline R-squared & 0.13 & 0.13 & 0.13 & 0.12 & 0.12 & 0.12 & 0.12 & 0.12 & 0.12 \\
\hline
\end{tabular}

Notes: Standard errors in parentheses are clustered on CMSA. +, *,** indicate staistical significance at the 10, 5, and 1 percent level respectively. See appendix text for additional details. 
Appendix Table 5. 1970-2000 Analysis

\begin{tabular}{|c|c|c|c|c|c|c|}
\hline \multirow[t]{2}{*}{ Dependent Variable: Married } & \multicolumn{3}{|c|}{ White Men (mean=0.611) } & \multicolumn{3}{|c|}{ Black Men $($ mean=0.432) } \\
\hline & $\begin{array}{c}\text { Race/Ethnicity } \\
\text { Based } \\
\text { Reference } \\
\text { Groups } \\
\text { I } \\
\end{array}$ & $\begin{array}{l}\text { Education } \\
\text { Based } \\
\text { Reference } \\
\text { Groups } \\
\text { II } \\
\end{array}$ & $\begin{array}{c}\text { Race/Ethnicity } \\
\text { and Education } \\
\text { Based } \\
\text { Reference } \\
\text { Groups } \\
\text { III } \\
\end{array}$ & $\begin{array}{c}\text { Race/Ethnicity } \\
\text { Based } \\
\text { Reference } \\
\text { Groups } \\
\text { IV } \\
\end{array}$ & $\begin{array}{c}\text { Education } \\
\text { Based } \\
\text { Reference } \\
\text { Groups } \\
\text { V } \\
\end{array}$ & $\begin{array}{c}\text { Race/Ethnicity } \\
\text { and Education } \\
\text { Based } \\
\text { Reference } \\
\text { Groups } \\
\text { VI } \\
\end{array}$ \\
\hline Ratio Income/Ideal if Under Marriage Ideal & $\begin{array}{c}\mathbf{0 . 2 5 2 3} * * \\
(0.0603)\end{array}$ & $\begin{array}{c}\mathbf{0 . 3 4 5 7 * *} \\
(0.0245)\end{array}$ & $\begin{array}{c}\mathbf{0 . 3 9 1 2} * * \\
(0.0240)\end{array}$ & $\begin{array}{c}\mathbf{0 . 1 6 9 9}^{* *} \\
(0.0495)\end{array}$ & $\begin{array}{c}\mathbf{0 . 2 0 4 8} * * \\
(0.0408)\end{array}$ & $\begin{array}{c}\mathbf{0 . 1 5 9 6}^{* *} \\
(0.0321)\end{array}$ \\
\hline Ratio Income/Ideal if Over Marriage Ideal & $\begin{array}{c}\mathbf{0 . 0 2 1 1} \\
(0.0350)\end{array}$ & $\begin{array}{c}\mathbf{0 . 1 1 1 7} * * \\
(0.0124)\end{array}$ & $\begin{array}{c}\mathbf{0 . 1 2 5 8}^{* *} \\
(0.0135)\end{array}$ & $\begin{array}{c}\mathbf{0 . 0 7 4 7}^{*} \\
(0.0367)\end{array}$ & $\begin{array}{c}\mathbf{0 . 0 1 7 2} \\
(0.0379)\end{array}$ & $\begin{array}{l}\mathbf{0 . 0 5 9 5 *} \\
(0.0235)\end{array}$ \\
\hline Under Marriage Ideal & $\begin{array}{c}-\mathbf{0 . 2 2 3 1} * * \\
(0.0420)\end{array}$ & $\begin{array}{c}\mathbf{- 0 . 2 3 5 5 * *} \\
(0.0143)\end{array}$ & $\begin{array}{c}-\mathbf{0 . 2 6 2 3} * * \\
(0.0158)\end{array}$ & $\begin{array}{c}\mathbf{- 0 . 0 9 5 3 *} \\
(0.0435)\end{array}$ & $\begin{array}{c}\mathbf{- 0 . 1 8 3 9} * * \\
(0.0428)\end{array}$ & $\begin{array}{c}\mathbf{- 0 . 1 0 9 5} * * \\
(0.0318)\end{array}$ \\
\hline Decile Rank in CMSA-Race/Eth Group Dummies & yes & yes & yes & yes & yes & yes \\
\hline Year-Specific Adjusted Income Dummies & yes & yes & yes & yes & yes & yes \\
\hline Age Dummies & yes & yes & yes & yes & yes & yes \\
\hline Year*Ed Group Dummies & yes & yes & yes & yes & yes & yes \\
\hline Additional CMSA controls & yes & yes & yes & yes & yes & yes \\
\hline CMSA Dummies & yes & yes & yes & yes & yes & yes \\
\hline Number of Observations & 1173124 & 1173124 & 1173124 & 145736 & 145736 & 145730 \\
\hline Number of CMSA-Year Cells & 376 & 376 & 376 & 304 & 304 & 304 \\
\hline R-squared & 0.16 & 0.16 & 0.16 & 0.16 & 0.16 & 0.16 \\
\hline
\end{tabular}

Notes: Standard errors in parentheses are clustered on CMSA. +, *,** indicate staistical significance at the 10, 5, and 1 percent level respectively. See appendix text for additional details. 